Research article

urn:lsid:zoobank.org:pub:F8E6FEEF-FC7A-4B40-AEEE-95DBC7BC61A4

\title{
Osteology and relationships of Libanopycnodus wenzi gen. et sp. nov. and Sigmapycnodus giganteus gen. et sp. nov. (Pycnodontiformes) from the Late Cretaceous of Lebanon
}

\author{
Louis TAVERNE ${ }^{1} \&$ Luigi CAPASSO ${ }^{2}$ \\ ${ }^{1}$ Royal Institute of Natural Sciences of Belgium, Directorate Earth and History of Live, \\ Vautierstraat 29, B-1000 Brussels, Belgium. \\ ${ }^{2}$ Museo Universitario dell’Universitá “G. d'Annunzio" di Chieti-Pescara, \\ Piazza Trento e Trieste 1, I-661000 Chieti, Italy. \\ ${ }^{*}$ Corresponding author: louis.taverne@gmail.com \\ 2Email: 1capasso@unich.it \\ ${ }^{1}$ urn:1sid:zoobank.org:author:0CF81641-1DD1-4CBD-9735-F1FE7EB0BCF5 \\ ${ }^{2}$ urn:lsid:zoobank.org:author:C79C14CF-C1D7-48E3-9BA9-CAD8AA0909F7
}

\begin{abstract}
The skeleton and the relationships of Libanopycnodus wenzi gen. et sp. nov. and of Sigmapycnodus giganteus gen. et sp. nov., two pycnodontiform fishes from the marine Cenomanian (Late Cretaceous) of Lebanon, are studied in detail. Both species belong to the family Pycnodontidae, as shown by their parietal brush-like process. Some osteological characters (bifid cloacal scale, large well visible dilatator fossa surrounded by the dermosphenotic and the dermopterotic, etc.) indicate that they are members of the subfamily Pycnodontinae. Libanopycnodus gen. nov. has the preopercle much deeper than the exposed region of the hyomandibula-dermohyomandibula and is the most primitive genus of this lineage. Sigmapycnodus gen. nov. is one of the most advanced members of the subfamily. It shares with Oropycnodus Poyato-Ariza \& Wenz, 2002 and Pycnodus Agassiz, 1833 an apomorphy not present in the less specialized Pycnodontinae, the arcocentra in hypercomplex contact.
\end{abstract}

Keywords. Pycnodontinae, Libanopycnodus wenzi gen. et sp. nov., Sigmapycnodus giganteus gen. et sp. nov., osteology, relationships, Cretaceous, Lebanon.

Taverne L. \& Capasso L. 2018. Osteology and relationships of Libanopycnodus wenzi gen. et sp. nov. and Sigmapycnodus giganteus gen. et sp. nov. (Pycnodontiformes) from the Late Cretaceous of Lebanon. European Journal of Taxonomy 420: 1-29. https://doi.org/10.5852/ejt.2018.420

\section{Introduction}

Pycnodontomorpha are the largest group within the halecostome fishes, with an almost worldwide distribution, ranging from the Late Triassic to the Middle Eocene (Nursall 1996; Kriwet 2001; MartinAbad \& Poyato-Ariza 2013). 
These fossil fishes represent by far the richest and the most diversified neopterygian lineage within the marine Late Cretaceous ichthyofauna of Lebanon. The Lebanese members of that lineage comprise not only many genera with a typical pycnodontid morphotype, but also some highly specialized families with horns and spines, such as the Coccodontidae (Taverne \& Capasso 2014a), the Gebrayelichthyidae (Taverne \& Capasso 2014b) and the Gladiopycnodontidae (Taverne \& Capasso 2013, 2014c, 2016; Taverne et al. 2015; Marrama et al. 2016).

The aim of our paper is to describe and to determine the relationships of two new Lebanese genera belonging to the subfamily Pycnodontinae.

\section{Material and methods}

The specimens studied here belong to the Capasso's collection (CLC) in Chieti, Italy. This collection is legally registered by a decree of the Ministero per I Beni e le Attività Culturali under the date of October $11^{\text {th }} 1999$, following the disposition of the Italian law 1089/39. The specimens of this collection also follow to prescriptions of the Italian law 42/2004, article 30, in matters of conservation and availability for studies. The Soprintendenza per I Beni Archeologici dell'Abruzzo-Chieti has authorized the authors to study this collection by two letters bearing the dates of May $5^{\text {th }}, 2011$ (reference: MBAC-SBA-ABR PROT 0004537 05/05/2011 CL.34.25.01/2.1) and July 30 $0^{\text {th }}, 2014$ (reference: MBAC-SBA-ABR PROT 0005618 31/07/2014 CL. 34.25.01/2.1).

The material was studied with a stereo microscope Leica Wild M 8. The drawings of the figures were drawn by the first author (L.T.). The photos were made by M. Luciano Lullo, from the University "G. d'Annunzio" of Chieti-Pescara. Aspersions with ethanol were used to improve some observations.

List of abbreviations used in text-figures:

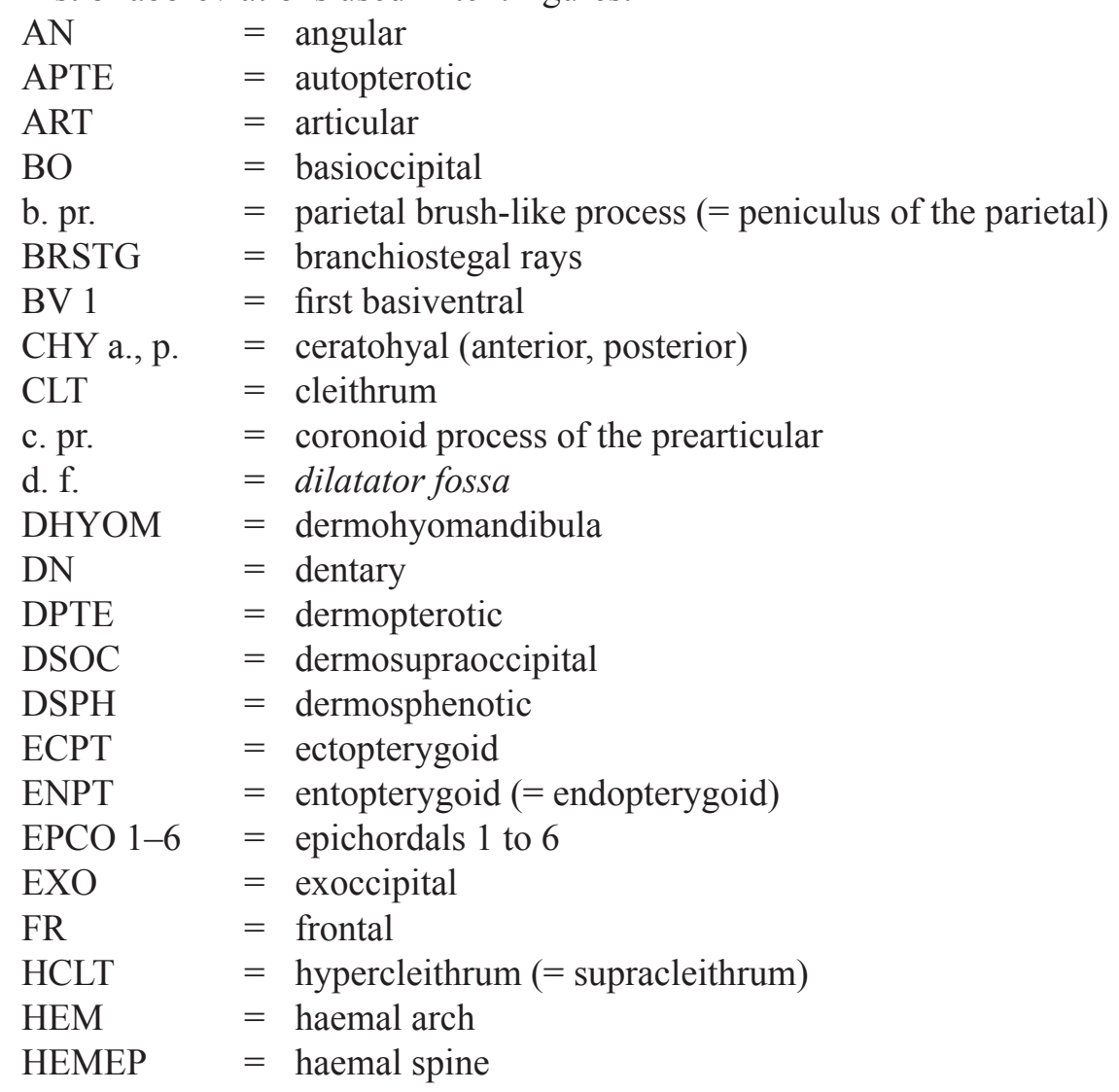




$$
\begin{aligned}
& \text { HP } 1-17=\text { haemal spines } 1 \text { to } 17 \\
& \text { HYCO 1-11 = hypochordals } 1 \text { to } 11 \\
& \text { HYOM }=\text { hyomandibula } \\
& \text { IC }=\text { intercalar } \\
& \text { IORB }=\text { infraorbital } \\
& \text { IORB } 1=\text { enlarged first infraorbital } \\
& \text { 1. }=\text { left } \\
& \text { LEP } \quad=\text { lepidotrichium (= ray) } \\
& \text { METH }=\text { mesethmoid } \\
& \text { MPT }=\text { metapterygoid } \\
& \text { MX } \quad=\text { maxilla } \\
& \text { NEUR } \quad=\text { neural arch } \\
& \text { NEUREP }=\text { neural spine } \\
& \text { NP } 1-41=\text { neural spines } 1 \text { to } 41 \\
& \mathrm{OP}=\text { opercle } \\
& \mathrm{OSPH}=\text { orbitosphenoid } \\
& \mathrm{PA}=\text { parietal } \\
& \text { PCLT }=\text { postcleithrum } \\
& \text { PCOEL = postcoelomic bone } \\
& \text { PMX }=\text { premaxilla } \\
& \text { POP }=\text { preopercle } \\
& \text { poz. }=\text { postzygapophysis } \\
& \text { PRART }=\text { prearticular } \\
& \text { PRFR }=\text { prefrontal } \\
& \text { prz. } \quad=\text { prezygapophysis } \\
& \text { PS }=\text { parasphenoid } \\
& \text { PT }=\text { posttemporal } \\
& \text { QU }=\text { quadrate } \\
& \text { r. } \quad=\text { right } \\
& \mathrm{RAD}=\text { pterygiophore }(=\text { radial }) \\
& \text { RAD d. } 1=\text { first dorsal pterygiophore }(=\text { first dorsal radial }) \\
& \text { RI } \quad \text { ribs } \\
& \mathrm{SC} \quad=\text { scales } \\
& \mathrm{SC} \mathrm{b.} \quad=\text { body scales } \\
& \text { SC bi. } \quad=\text { bifid cloacal scale } \\
& \text { SC 1.1. = scale of the lateral line } \\
& \text { SCL }=\text { sclerotic bone } \\
& \text { SCU d. 1-11 = scutes of the dorsal ridge (1 to 11) } \\
& \text { SCU v. } 1-13=\text { scutes of the ventral keel (1 to 13) } \\
& \text { ST } \quad=\text { supratemporal }(=\text { modified scale }) \\
& \text { SY } \quad=\text { symplectic } \\
& \text { UD } \quad=\text { urodermal } \\
& \text { UHY } \quad=\text { urohyal }(=\text { parahyoid }) \\
& \mathrm{VO} \quad=\text { vomer } \\
& \text { w. np. = wing component of the neural spine }
\end{aligned}
$$




\section{Results}

Subclass Actinopterygii Klein, 1885

Series Neopterygii Regan, 1923

Division Halecostomi Regan, 1923 sensu Patterson 1973

Superorder Pycnodontomorpha Nursall, 2010

Order Pycnodontiformes Berg, 1937 sensu Nursall 2010

Family Pycnodontidae Agassiz, 1833 sensu Nursall 1996

Subfamily Pycnodontinae Poyato-Ariza \& Wenz, 2002

Genus Libanopycnodus gen. nov.

urn:1sid:zoobank.org:act:30B10E58-4147-4982-ADE0-B5956A502764

\section{Type species}

Libanopycnodus wenzi gen. and sp. nov. (by monotypy).

\section{Diagnosis}

As for the species (monospecific genus).

\section{Etymology}

The generic eptithet refers to Lebanon and the taxon name Pycnodus is added.

Libanopycnodus wenzi gen. et sp. nov.

urn:1sid:zoobank.org:act:2AD09A18-0416-4A26-AD08-E5307B901759

Figs 1-11

\section{Diagnosis}

Small, deep-bodied pycnodontid fish, with rounded dorsal and ventral profiles. Head triangular in shape, with a rectilinear frontal profile and a short postorbital region. Pointed snout, with a mouth gape ventrally inclined. Frontal short. Prefrontal very narrow. Dorsal region of parietal forming a marked angle with the ventral region. Parietal brush-like process present. No temporal fenestra. Dermosphenotic sutured to the skull roof. Large, deep, well-visible dilatator fossa surrounded by dermosphenotic and dermopterotic. Posterior region of the endocranium exposed behind the dermopterotic. Vomer with 10 rounded molariform teeth on the external dental row. Premaxilla bearing two incisiform teeth. Prearticular with three rows of molariform teeth. Ectopterygoid present. Large triangular first infraorbital. Preopercle much deeper than the exposed region of the hyomandibula-dermohyomandibula. Opercle small and coma-shaped. Notochord not completely surrounded by vertebral arches. Neural and haemal spines with an anterior wing-like component. Twenty-five neural spines before epichordal series. First eight neural spines autogenous. Twelve haemal spines before hypochordal series. Eleven pairs of ribs. Postcoelomic bone long, narrow, with an enlarged ventral extremity. Dorsal and anal fins strip-like. Dorsal fin supported by 42 pterygiophores. Anal fin supported by 34 pterygiophores. Caudal peduncle short. Five epichordals. Eleven hypochordals, with two moderately broadened. One urodermal. Caudal fin double emarginated, with 20 principal rays. A few scale bars on the abdominal region of the body. Small complete scales associated with the prepelvic ventral keel scutes. Bifid cloacal scale present. One postcloacal scale. Dorsal ridge with 11 scutes, of which the first two with a small spine. Ventral keel with 13 scutes, 11 prepelvic and two postcloacal with small spines. 
TAVERNE L. \& CAPASSO L., Two new pycnodontiform fishes from the Cretaceous of Lebanon

\section{Etymology}

The specific epithet is in homage to Dr. Sylvie Wenz (Paris), who worked abundantly on the pycnodontiform fishes.

\section{Material examined}

\section{Holotype}

LEBANON: a complete specimen (Figs 1-2), total length: $90 \mathrm{~mm}$, standard length: $78 \mathrm{~mm}$, marine Upper Cenomanian deposits of Ein Namoura (CLC S-574).

\section{General morphology and morphometric data}

The fish is deep-bodied, the maximum body height being equal to a little more than the half of the standard length. The dorsal and the ventral profiles are rounded and devoid of marked apex.

The morphometric data are given in \% of the standard length $(78 \mathrm{~mm})$ :

Length of the head (opercle included)

$34.0 \%$

Depth of the head (in the occipital region)

$44.7 \%$

Maximum depth of the body (just behind the head)

$56.2 \%$

Prepelvic length

$57.0 \%$

Predorsal length

$68.1 \%$

Basal length of the dorsal fin

$35.7 \%$

Preanal length

$71.5 \%$

Basal length of the anal fin

$28.9 \%$

Depth of the caudal peduncle

$.7 .2 \%$

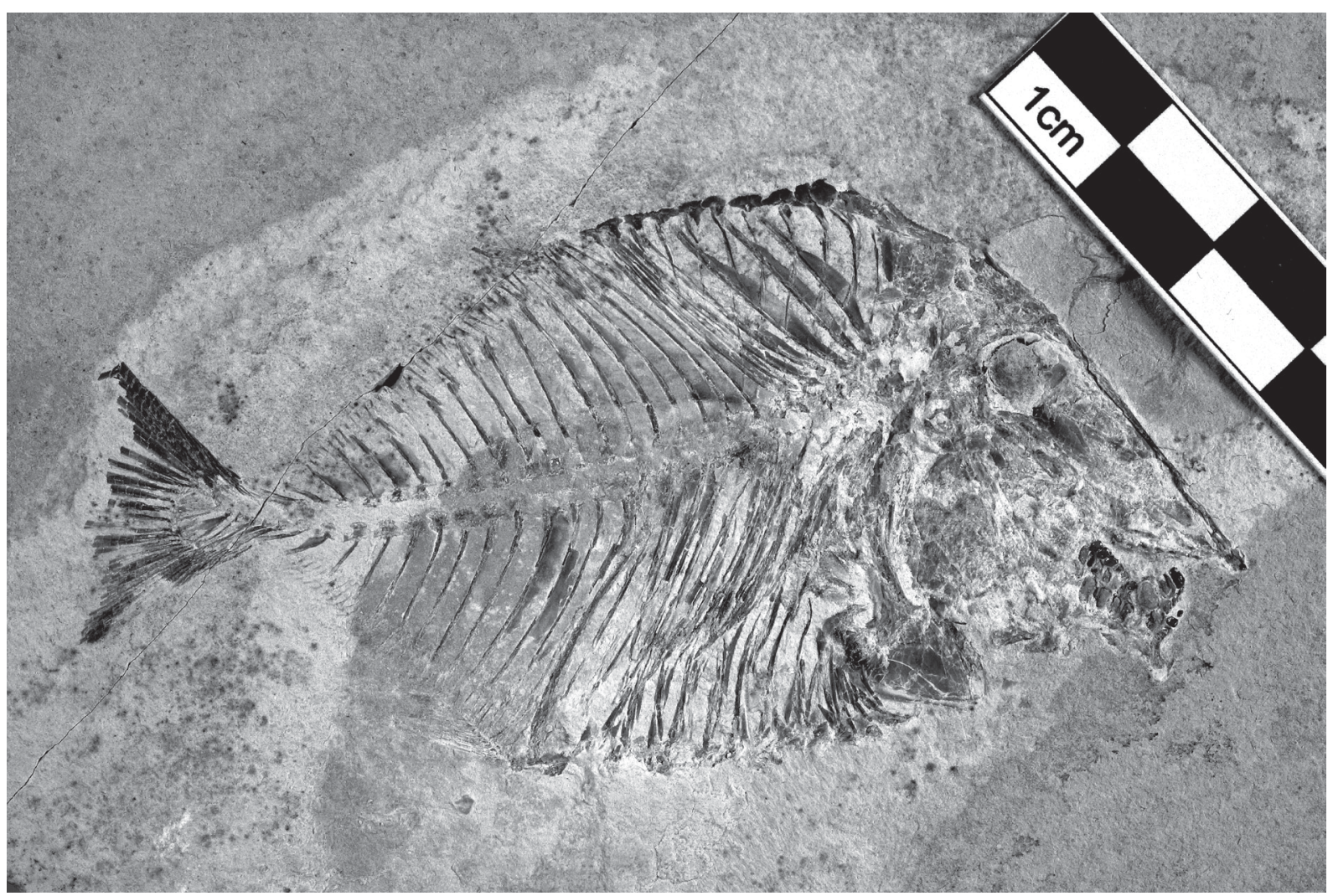

Fig. 1. Libanopycnodus wenzi gen. et sp. nov., holotype (CLC S-574). 


\section{Osteology}

\section{Skull (Figs 3-6)}

The head is large, triangular in shape, altogether long and deep, with an almost rectilinear frontal profile. The preorbital region is much longer than the postorbital one. The orbit is wide. The dermal bones of the skull are ornamented with small tubercles. The snout is pointed, with a mouth gape ventrally inclined.

The mesethmoid is elongate and broad. Its upper margin is covered posteriorly by a pair of very narrow prefrontals and anteriorly by the premaxillae. The orbitosphenoid is pressed against the posterior margin of the mesethmoid. The vomer, seen in profile, is long and deeper posteriorly than anteriorly. Only the lateral dental row, composed of 7 well-developed, rounded molariform teeth, is visible. There are traces of 3 other very small teeth located at the anterior extremity of the lower margin of the vomer.

The frontal is short and limited to the orbital region. The dermosupraoccipital is small, with a pointed dorso-posterior extremity. The parietal exhibits an unusual and strange shape. Its dorsal half forms a marked angle with its ventral part. This peculiar shape of the parietal is not due to an artefact of fossilisation. A short brush-like process (= branched peniculus) is attached to the parietal. The supratemporal is a rather broad scale that lies against the upper part of the parietal, just below the first dorsal ridge scute. The dermopterotic is deeper than long. The dermosphenotic is not a free bone. It is included in the lateral wall of the skull roof and is sutured with the frontal and the dermopterotic. The ventral margin of the dermosphenotic and the dermopterotic are located at the same level as the lower border of the orbit. The dermopterotic and the dermosphenotic surround a deep and wide dilatator fossa. The parasphenoid is long, broad, toothless and its trabercular region is obliquely inclined. The posterior region of the endocranium is well visible. A small part of the intercalar and the exoccipital are preserved behind the lower half of the parietal. The ventral margin of the exoccipital is pierced by

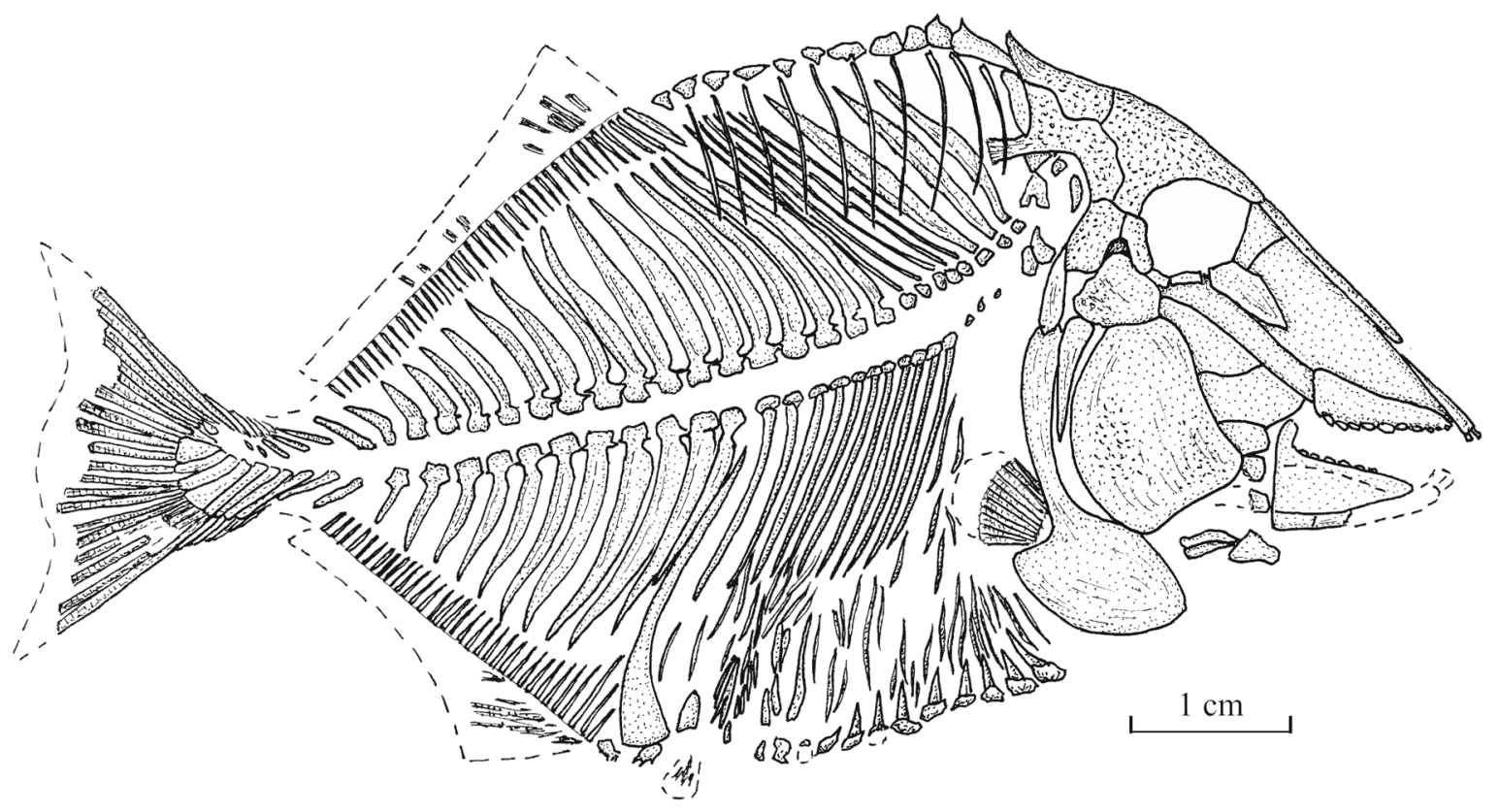

Fig. 2. Libanopycnodus wenzi gen. et sp. nov., holotype, reconstruction (CLC S-574). 
a large foramen for the branches of the vagus nerve (X). The basioccipital, articulated with the first basiventral, is also present. The exoccipital and basioccipital are separated from the braincase main part as in Pseudopycnodus nardoensis (Taverne 1997: fig. 2). A cartilaginous region probably linked the two cranial regions on the living fish. The autosphenotic and the sensory canals of the skull roof are not visible. A temporal fenestra is not present.

The quadratic arch includes wide metapterygoid and entopterygoid plus a small ectopterygoid. Only the anterior parts of the quadrate and the symplectic are preserved. Both bones articulate with the lower jaw. The articular head of the symplectic is very broad.

The premaxilla is long and narrow. It bears two incisiform teeth. The maxilla is lost. The posterior extremity of the dentary is preserved but not its anterior part with the teeth. The articular is small. The angular is not preserved. The prearticular is a large bone with a marked hook-like coronoid process, bearing three rows of molariform teeth. The dorsal row contains 6 teeth, the middle row 7 teeth and the ventral row at least 5 teeth. The teeth of the dorsal row are the smallest, with a slightly concave surface and their dorsal margin bears some little tubercles. The teeth of the lower row are the largest. They are deeper than long, with a slightly convex surface.

The orbital series contains four bones. The first infraorbital is a large triangular bone. The second and third infraorbitals are tubular bones. As already written, the dermosphenotic is sutured to the skull roof. A few fragments of the sclerotic bony ring are visible just under the frontal.

The exposed part of the hyomandibula-dermohyomandibula is much smaller than the preopercle to which it is sutured. The long ventral branch of the hyomandibula is covered by the preopercle but remains clearly visible. The upper margin of the hyomandibula bears a broad dorsal process that articulates in the dilatator fossa. The preopercle is deep and broad, with a rather narrow dorsal margin. The opercle is well developed, with an acuminate ventral tip and a broader upper part.

The anterior ceratohyal and two branchiostegal rays are visible below the preopercle.

\section{Girdles (Figs 3-4)}

A small posttemporal is preserved behind the skull, at the level of the suture between the parietal and the dermopterotic. The hypercleithrum (= supracleithrum) is a long and thin bone. The cleithrum is divided in a short but very broad ventral branch and an extremely long but narrow dorsal branch. No pterygiophore is preserved but fragments of short pectoral rays are visible.

The pelvic bones are not preserved but there are slight traces of the small pelvic fins under the cloacal region.

Axial skeleton (Figs 1-2, 7)

Starting from the tail region, the axial skeleton progressively elevates to reach anteriorly the level of the orbit. The vertebrae are formed by the dorsal and ventral arcocentra. There are no ossified vertebral centra, as in all pycnodonts. The neural and haemal arches are small and there is no dorso-ventral contact between them. So, the notochord is not completely surrounded by bony elements. In the caudal region, one small pre- and one small postzygapophysis link each neural arch with the following one. There are 25 neural spines before the epichordal series and 12 haemal spines before the hypochordal pieces. These spines bear anterior sagittal wings, except the fifth to the eighth neural spines that are pressed the ones against the others. The first 8 neural spines are autogenous. There are at least 11 pairs of long ribs. These ribs do not reach the ventral margin of the body. The postcoelomic bone is long and very narrow, except in its ventral part that is greatly enlarged. 


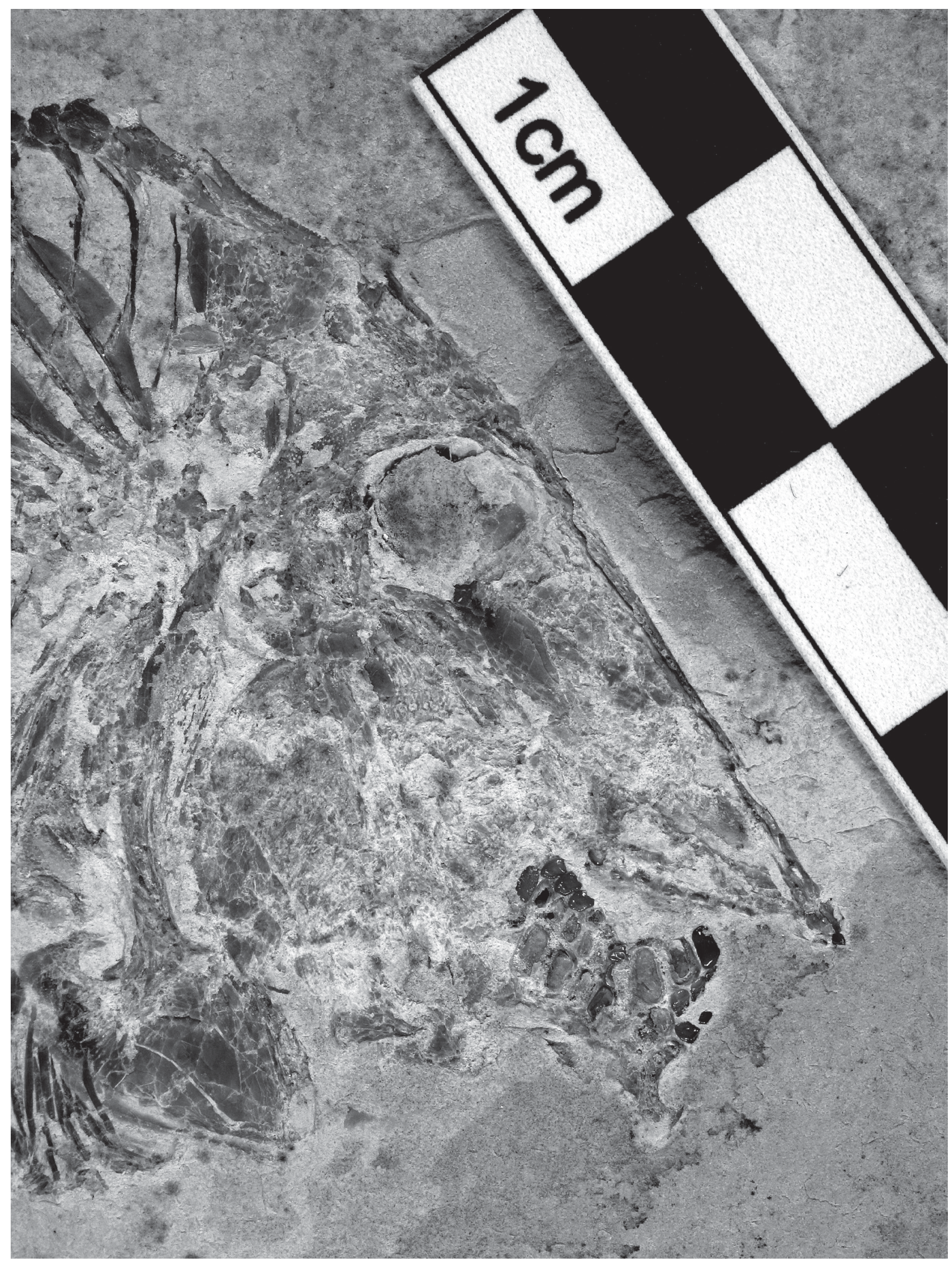

Fig. 3. Libanopycnodus wenzi gen. et sp. nov., holotype, head region (CLC S-574). 


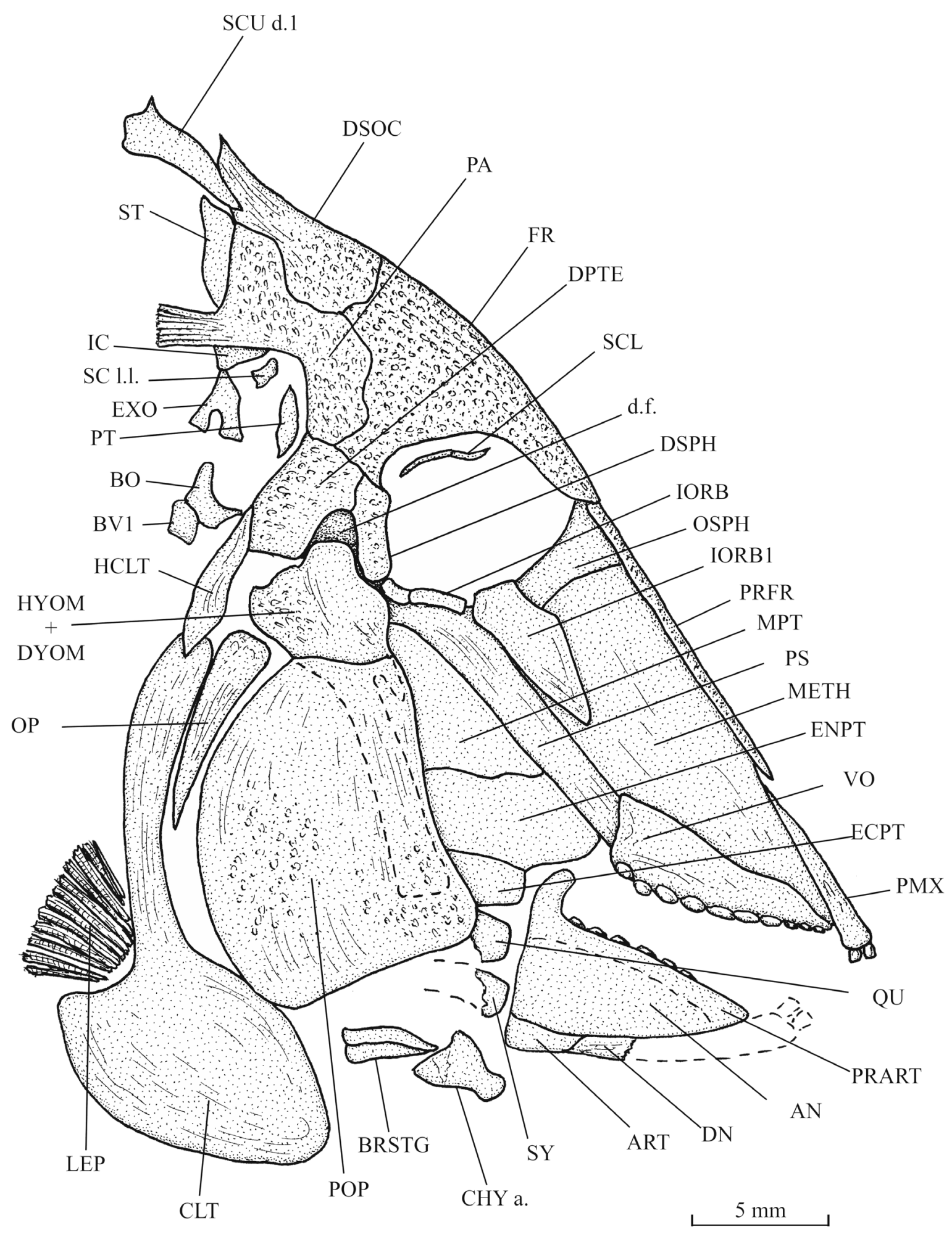

Fig. 4. Libanopycnodus wenzi gen. et sp. nov., holotype, skull and pectoral girdle (CLC S-574). 


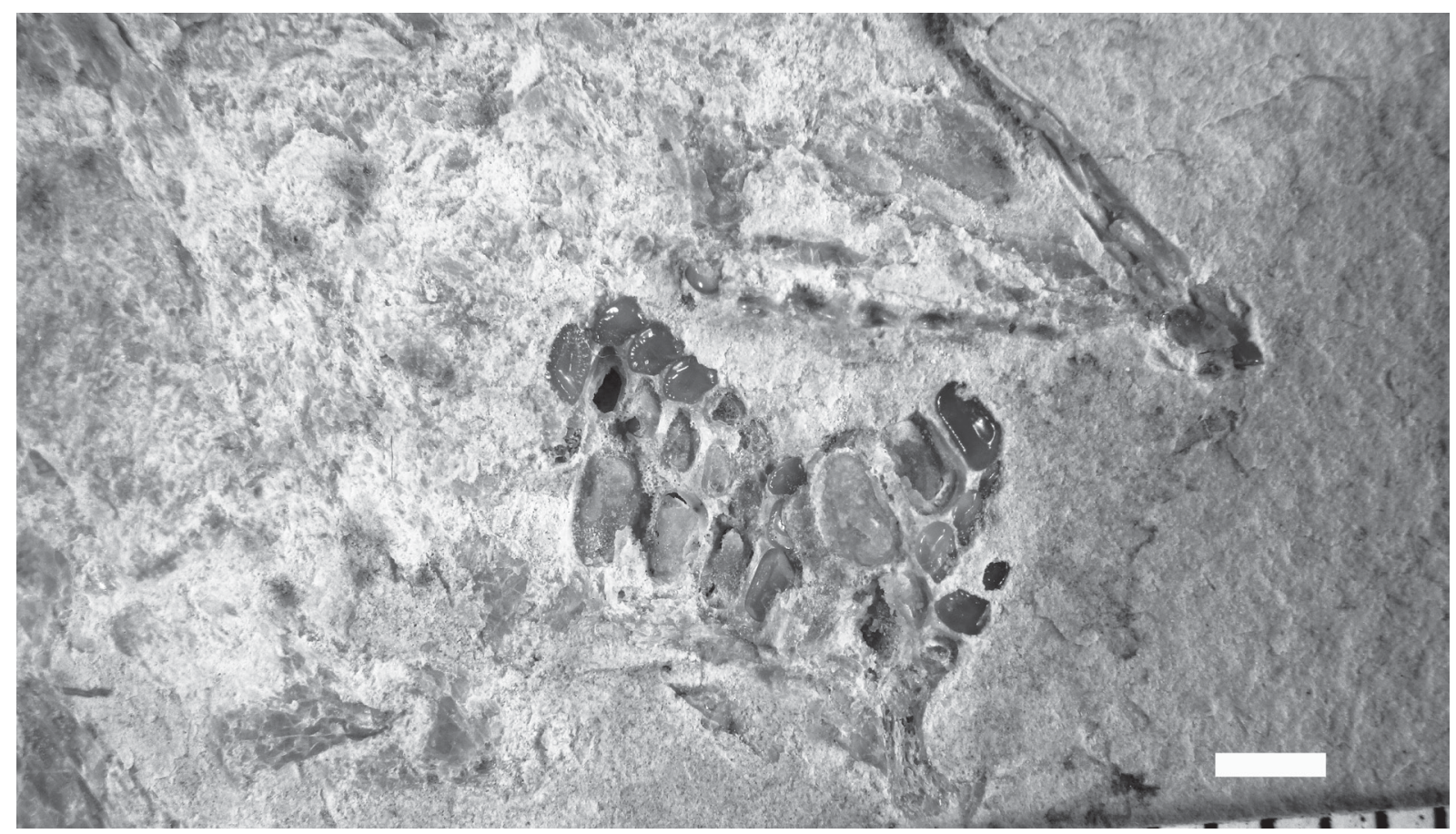

Fig. 5. Libanopycnodus wenzi gen. et sp. nov., holotype, snout, prearticulars and hyoid bar (CLC S-574). Scale bar: $2 \mathrm{~mm}$

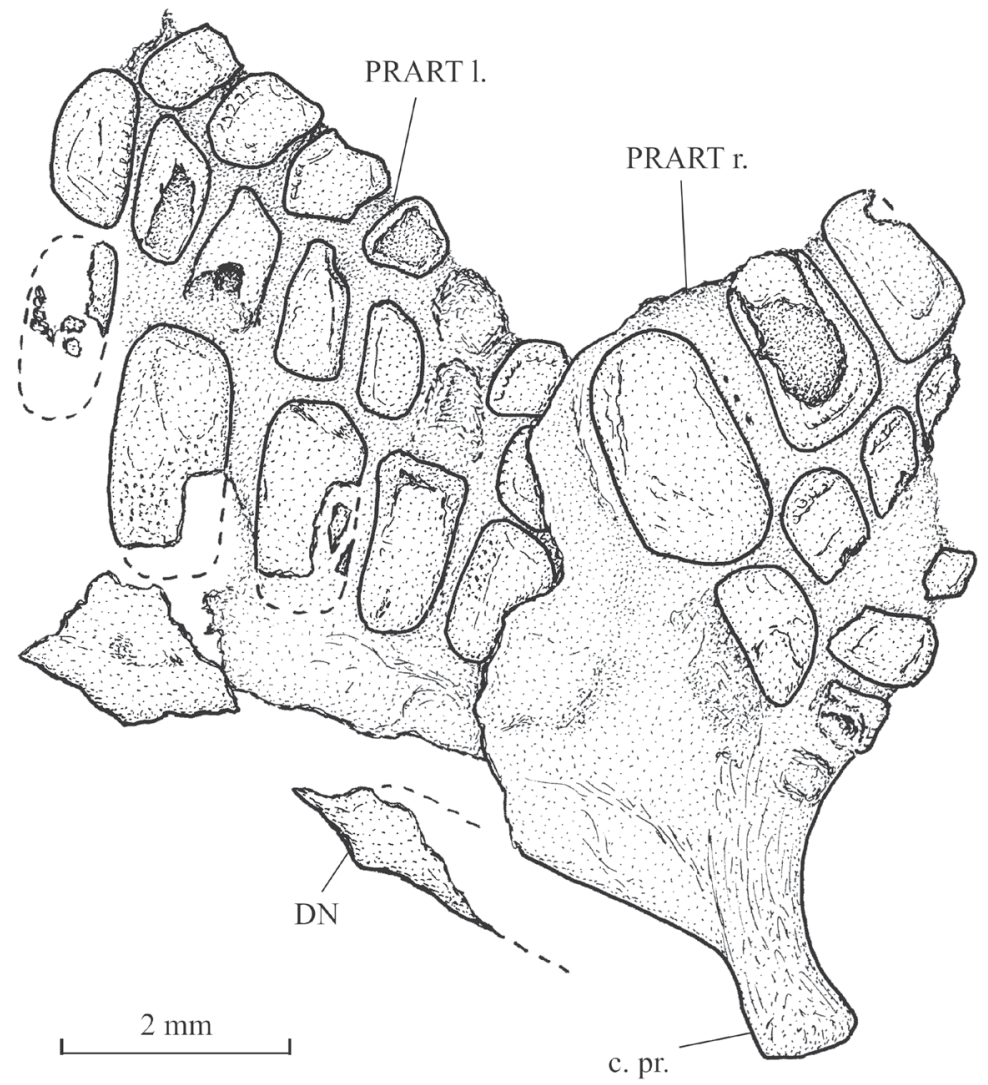

Fig. 6. Libanopycnodus wenzi gen. et sp. nov., holotype, the two prearticulars (CLC S-574). 


\section{Dorsal and anal fins (Figs 1-2)}

Both the dorsal and the anal fins are long and strip-like (type A 2 of Poyato-Ariza \& Wenz 2002: fig. 34). The origin of the dorsal fin is located far from the head. The dorsal fin is supported by 42 pterygiophores and the anal fin by 34 pterygiophores. Only a few fragments of the dorsal and anal fins are preserved. The precise number of these rays is not known.

\section{Caudal skeleton (Figs 8-9)}

The caudal peduncle is very short, the dorsal and anal fins ending near the tail. The caudal endoskeleton is composed of 5 epichordals, 11 hypochordals and 1 urodermal. The first three epichordals are thin and elongate. The last two elements of the series are extremely reduced. The hypochordals are longer and wider than the epichordals. The sixth and the ninth hypochordals are moderately broadened.

The caudal fin is double emarginated (Poyato-Ariza \& Wenz 2002: fig. 36E). There are 20 principal caudal rays, five dorsal and five ventral procurrent rays.

\section{Squamation (Figs 2, 10-11)}

Flank scales are present only in the abdominal region of the body. Dorsally, there is a pair of elongate scale bars associated to each dorsal ridge scute, except the last one. The squamation is missing in the middle region of the body. Ventrally, the flank scale bars are shorter but more numerous. The most ventral scales are small and triangular in shape. They are associated with the ventral keel scutes.

A small scale, probably bearing the lateral line canal, is visible below the brush-like process of the parietal.

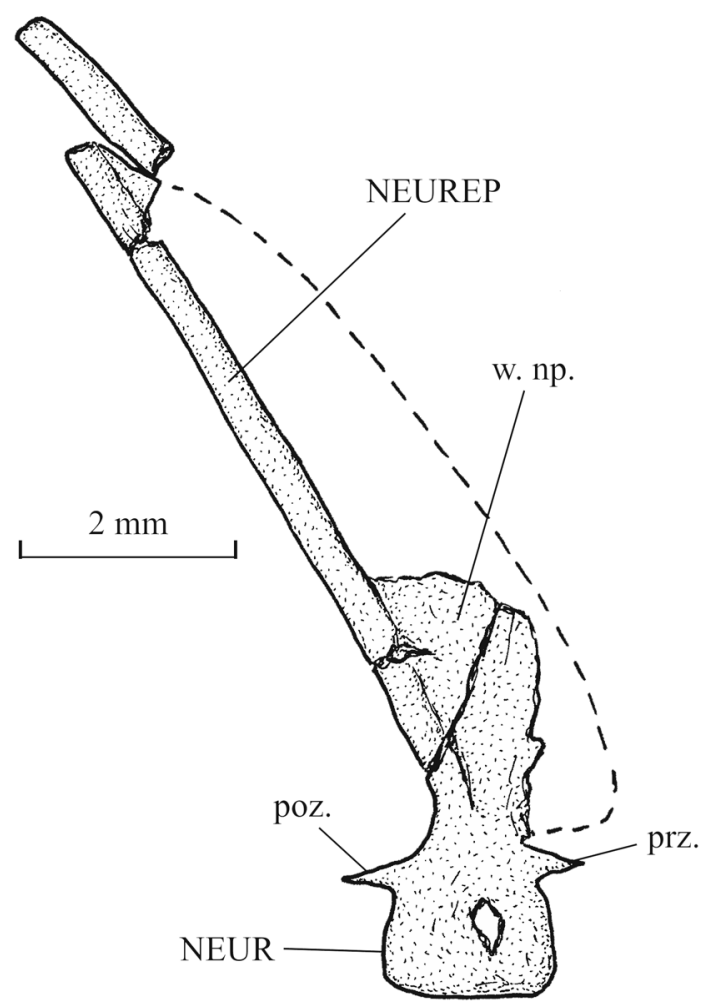

Fig. 7. Libanopycnodus wenzi gen. et sp. nov., holotype, eighteenth neural arch and spine (CLC S-574). 


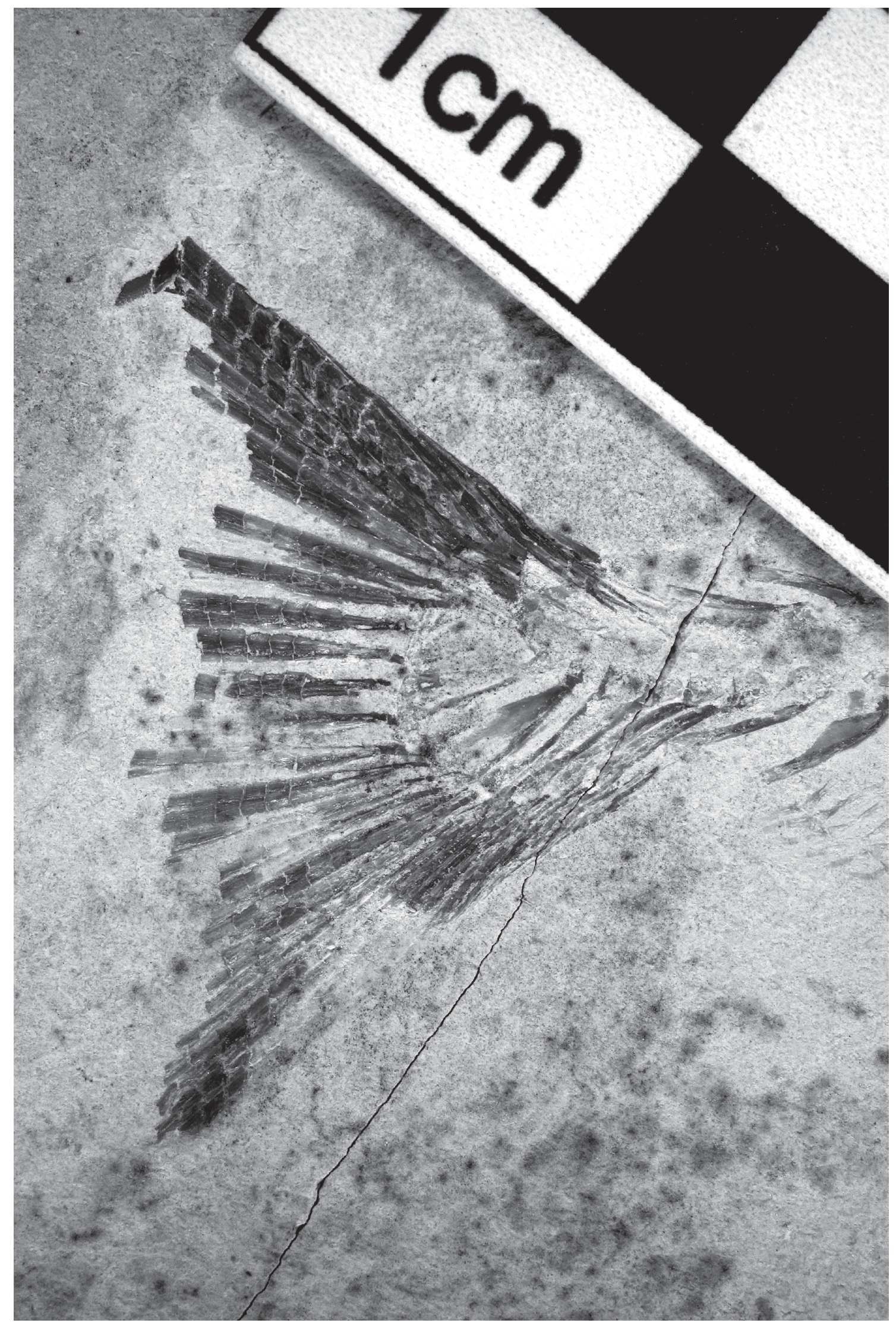

Fig. 8. Libanopycnodus wenzi gen. et sp. nov., holotype, tail region (CLC S-574). 


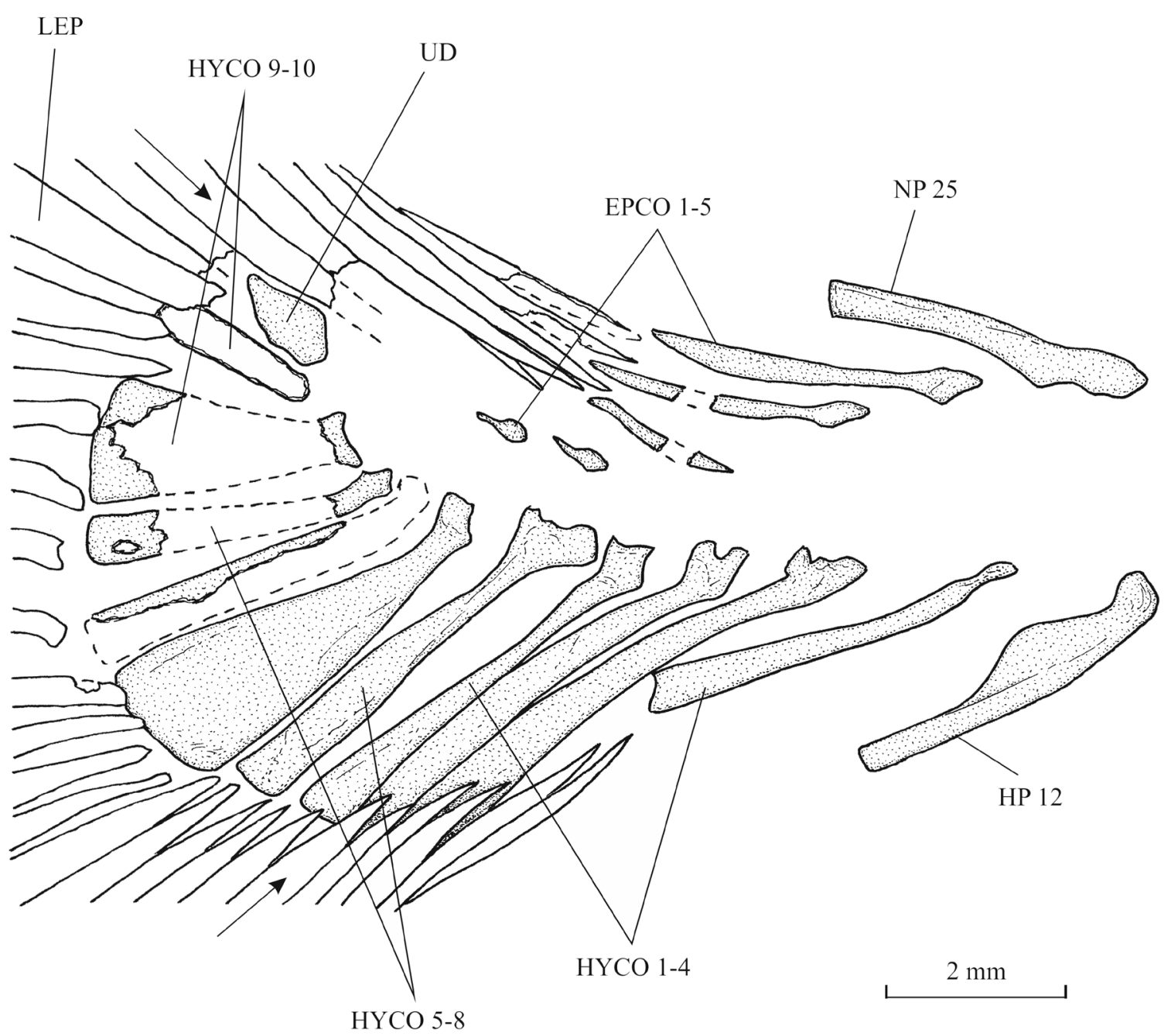

Fig. 9. Libanopycnodus wenzi gen. et sp. nov., holotype, caudal skeleton (CLC S-574). The arrows point to the two most external principal caudal rays.

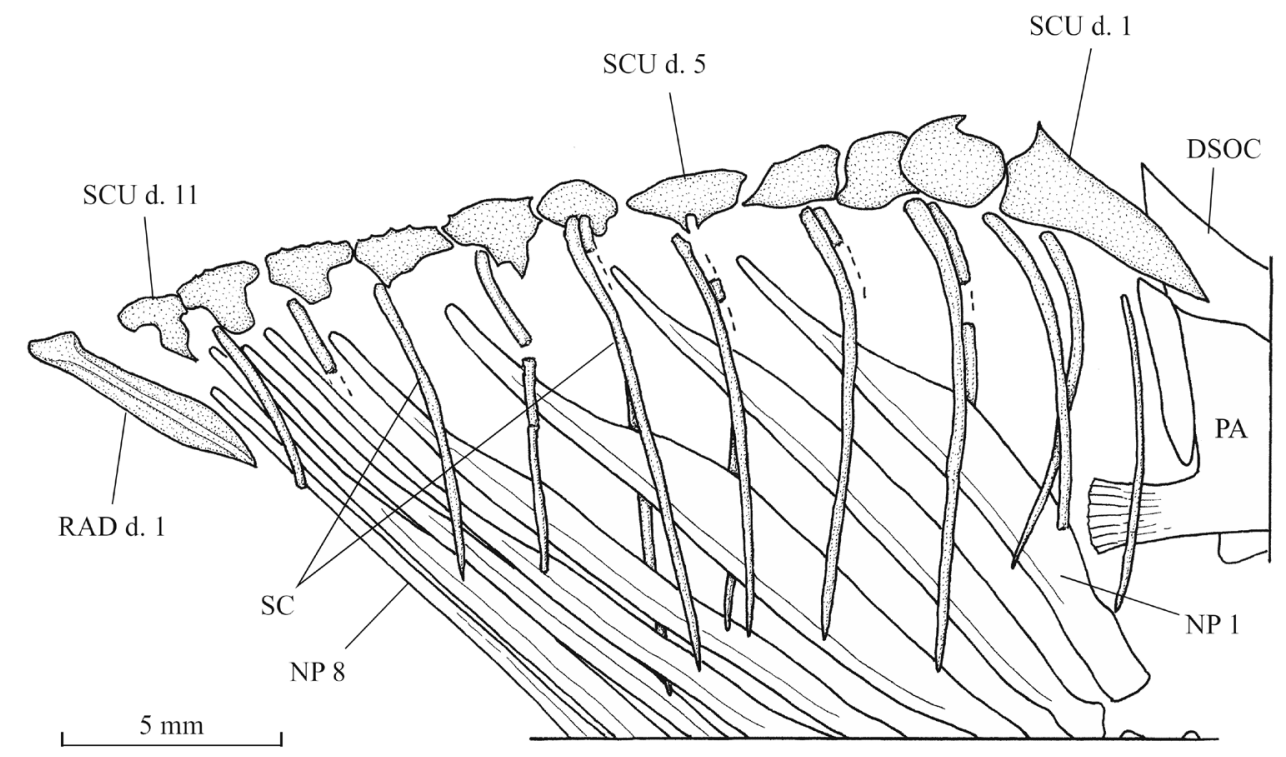

Fig. 10. Libanopycnodus wenzi gen. et sp. nov., holotype, dorsal ridge scutes (CLC S-574). 
There is a small narrow bifid cloacal scale and one broader postcloacal scale. The bifid cloacal scale is surrounded by a series of small scale bars. A long and rather broad scale is present just before the cloacal region.

The dorsal ridge is formed by 11 scutes. The first dorsal scute is articulated with the dermosupraoccipital and is longer than the following scutes. The first two elements of the series bear a small spine.

The ventral keel contains 13 scutes of which 11 prepelvic and two postcloacal associated to the postcoelomic bone. The 11 prepelvic scutes are very badly preserved and their shape is not determinable. The first postcloacal scute exhibits three small spines.

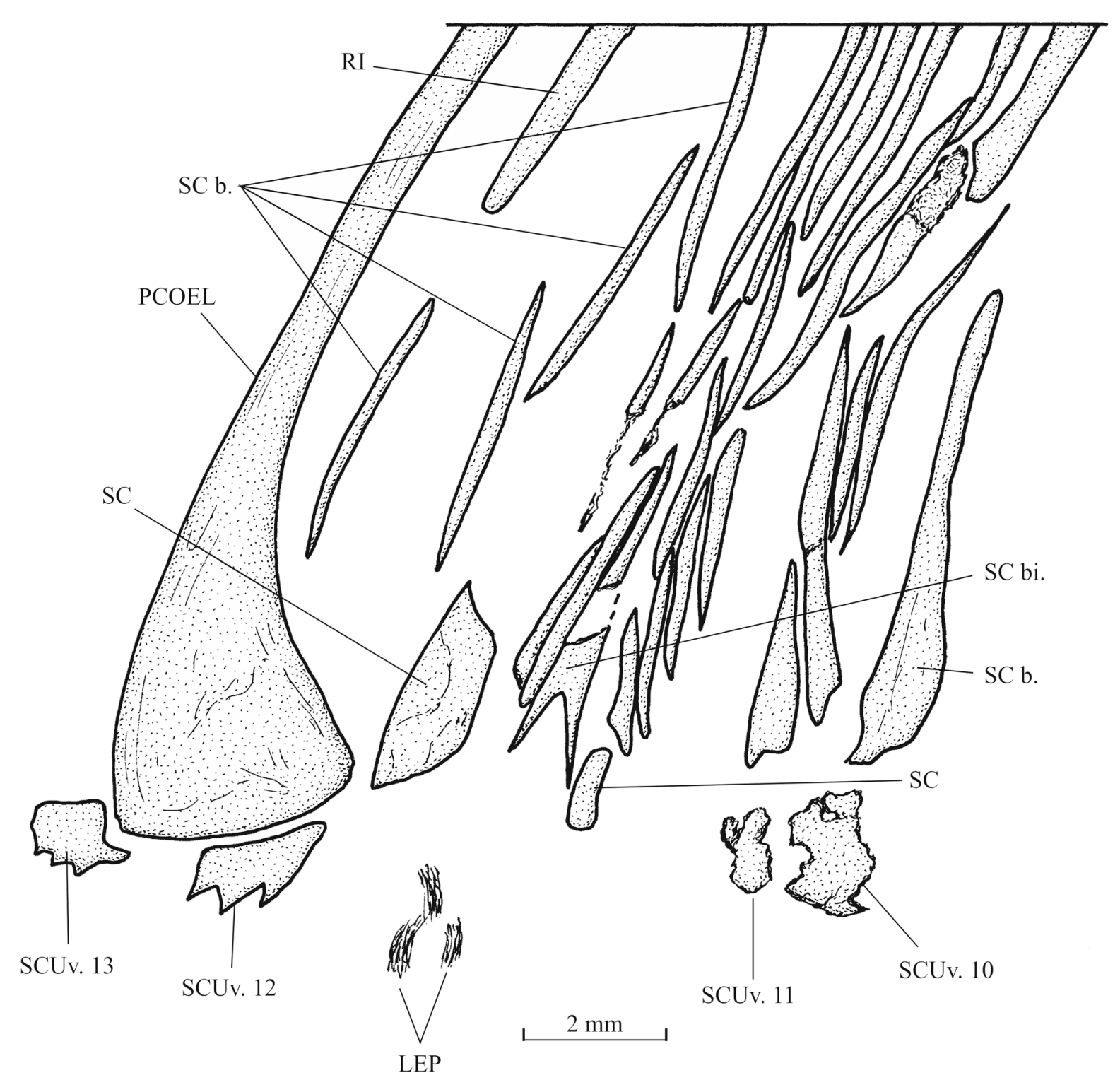

Fig. 11. Libanopycnodus wenzi gen. et sp. nov., holotype, cloacal region (CLC S-574). 
Genus Sigmapycnodus gen. nov. urn:1sid:zoobank.org:act:6855D3A7-D247-4065-81D2-26D5BD0ACF63

\section{Type species}

Sigmapycnodus giganteus gen. and sp. nov. (by monotypy).

\section{Diagnosis}

As for the species (monospecific genus).

\section{Etymology}

From the Greek letter 'sigma'. The taxon name Pycnodus is added. The generic name refers to the sigmoid frontal profile of the new fossil fish.

Sigmapycnodus giganteus gen. et sp. nov. urn:lsid:zoobank.org:act:3ED26D58-2200-4F11-A9C2-FD6046E3ADA1

Figs $12-22$

\section{Diagnosis}

Large pycnodontid fish, with a moderately deep body. Head deeper than long, with a sigmoid frontal profile and vertically oriented snout and mouth gape. Orbit small. Frontal short. Prefrontal long and broad. Parietal with a brush-like process. No temporal fenestra. Dermosphenotic sutured to the skull roof. Dermopterotic hypertrophied. Deep and extremely enlarged dilatator fossa surrounded by dermosphenotic and dermopterotic. Vomer bearing rounded globular-shaped teeth. Maxilla ovoid, with a notch in the posterior margin. Prearticular with two rows of molariform teeth. Ectopterygoid present. A series of six short tubular infraorbitals linking the orbital region to the snout. Preopercle as deep as the exposed region of the hyomandibula-dermohyomandibula. Small coma-shaped opercle. Notochord completely surrounded by vertebral arches. Arcocentra in hypercomplex contact in the caudal region. Neural and haemal spines with a wing-like component. Forty-one neural spines anterior to the epichordal series. Seventeen haemal spines before the hypochordal series. Eleven or 12 pairs of ribs. Postcoelomic bone long and thin. Origin of dorsal fin anterior to origin of anal fin. Caudal peduncle long. Six epichordals. Eleven hypochordals, of which some moderately broadened. One urodermal. Scale bars and a few ventral complete scales in the abdominal region of the body.

\section{Etymology}

From the Latin 'giganteus, a, um', gigantic. The specific name refers to the huge shape of the new fossil fish.

\section{Material examined}

Holotype

LEBANON: part and counterpart of a nearly complete specimen (Figs 12-13), total length: $66 \mathrm{~cm}$ (the posterior part of the caudal fin is missing), standard length: $59 \mathrm{~cm}$, marine Upper Cenomanian deposits of Haqel (CLC S-497a, b).

\section{General morphology and morphometric data (Fig. 14)}

Sigmapycnodus giganteus gen. et sp. nov. is a large pycnodontiform fish. Its total length is assumed to be ca $70 \mathrm{~cm}$ with the complete caudal fin. The body is not very high for a pycnodont, its depth being only equal to the half of the standard length. 


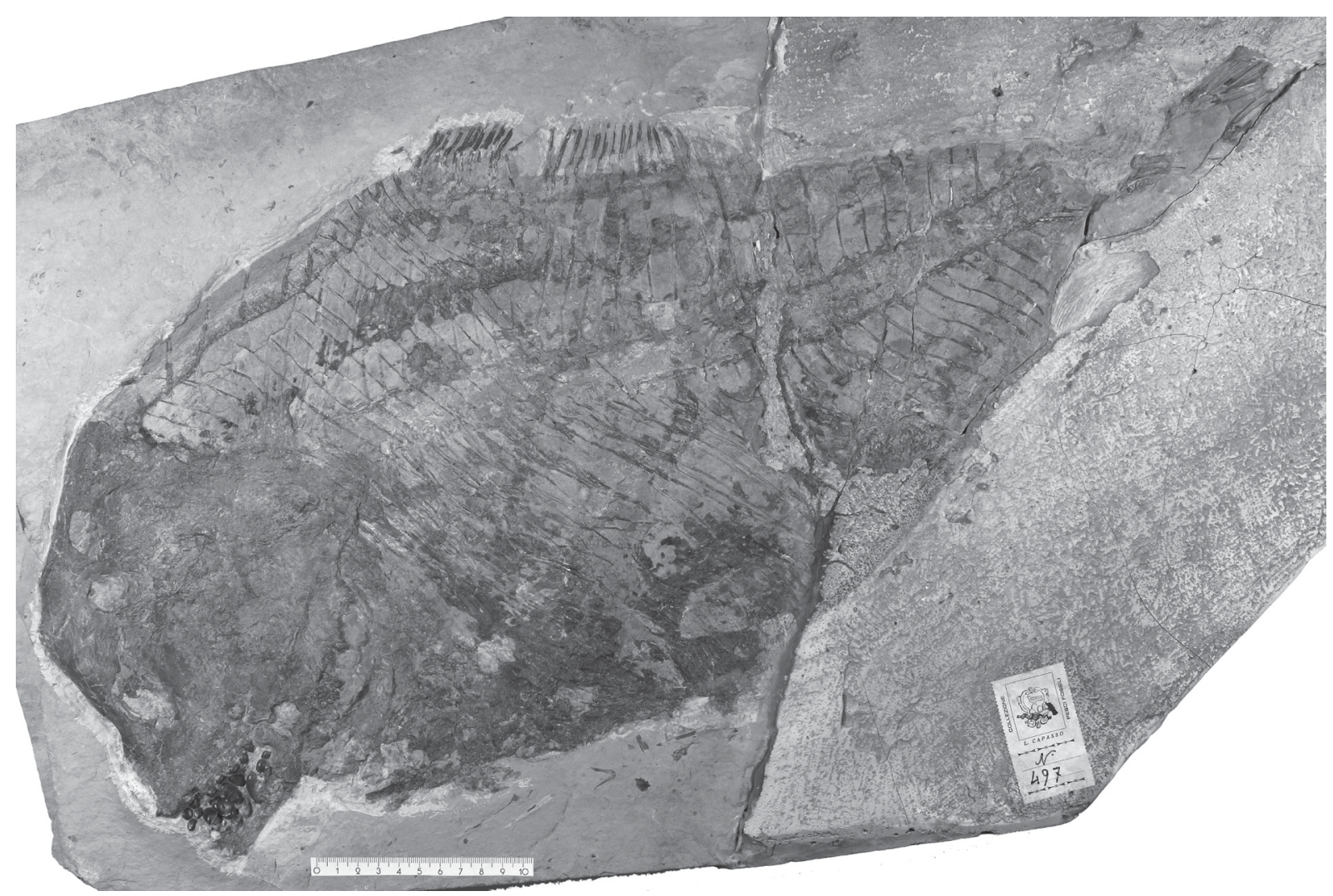

Fig. 12. Sigmapycnodus giganteus gen. et sp. nov., holotype (CLC S-497a), slab a.

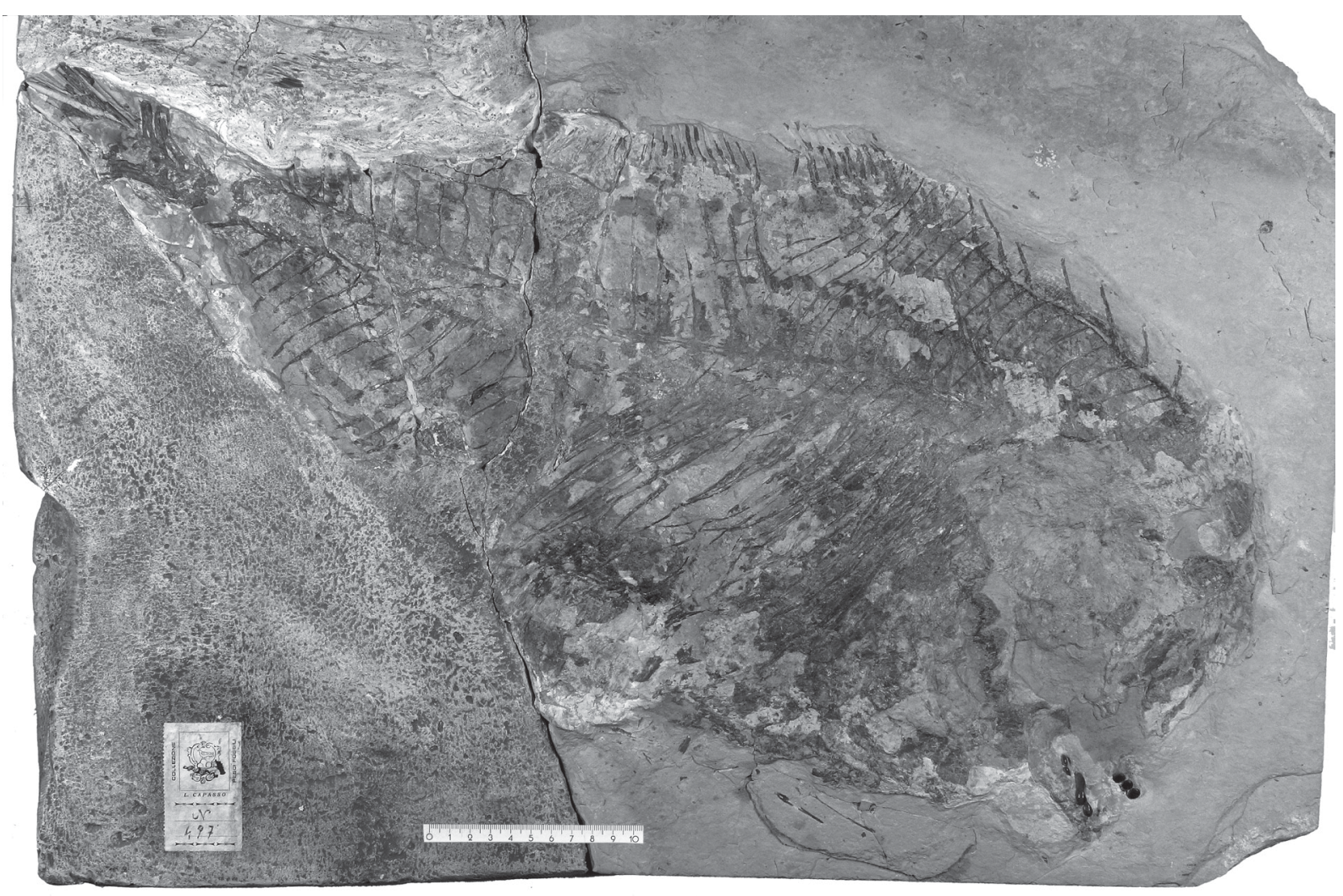

Fig. 13. Sigmapycnodus giganteus gen. et sp. nov., holotype (CLC S-497b), slab b. 
The morphometric data are given in $\%$ of the standard length $(59 \mathrm{~cm})$ :

Length of the head (opercle included)

Depth of the head (in the occipital region)

Maximum depth of the body (just before the dorsal fin)

Prepelvic length pelvic girdle not preserved

Predorsal length. $47.2 \%$

Basal length of the dorsal fin..... fin incomplete

Preanal length $58.5 \%$

Basal length of the anal fin.... fin incomplete

Depth of the caudal peduncle... not entirely preserved

\section{Osteology}

Skull (Figs 15-19)

The head is crushed and badly preserved. However, when combining the data given by the two slabs of the holotype, it is possible to reconstruct almost completely the skull.

The snout is short and vertically oriented. The frontal profile is sigmoid in shape, with a convex external margin at the level of the suture between the prefrontal and the frontal and a concave external margin lower on the prefrontal. The very small orbit is surrounded by the mesethmoid, the prefrontal, the frontal and the dermosphenotic. No endochondral bone of the braincase is visible, except the mesethmoid. The dermal bones of the skull bear some thin striae but this ornamentation is weakly developed.

The wide and deep mesethmoid is partly hidden by the long and broad prefrontal. The vomer is a large bone. Ten large molariform, rounded and globular-shaped teeth are visible. The first five are ranged in two rows and the posterior five in one row.

The frontal is short but rather broad. The dermosphenotic and the parietal are quite smaller. The parietal bears a long posterior brush-like process (= parietal peniculus) that is preserved as an imprint. The

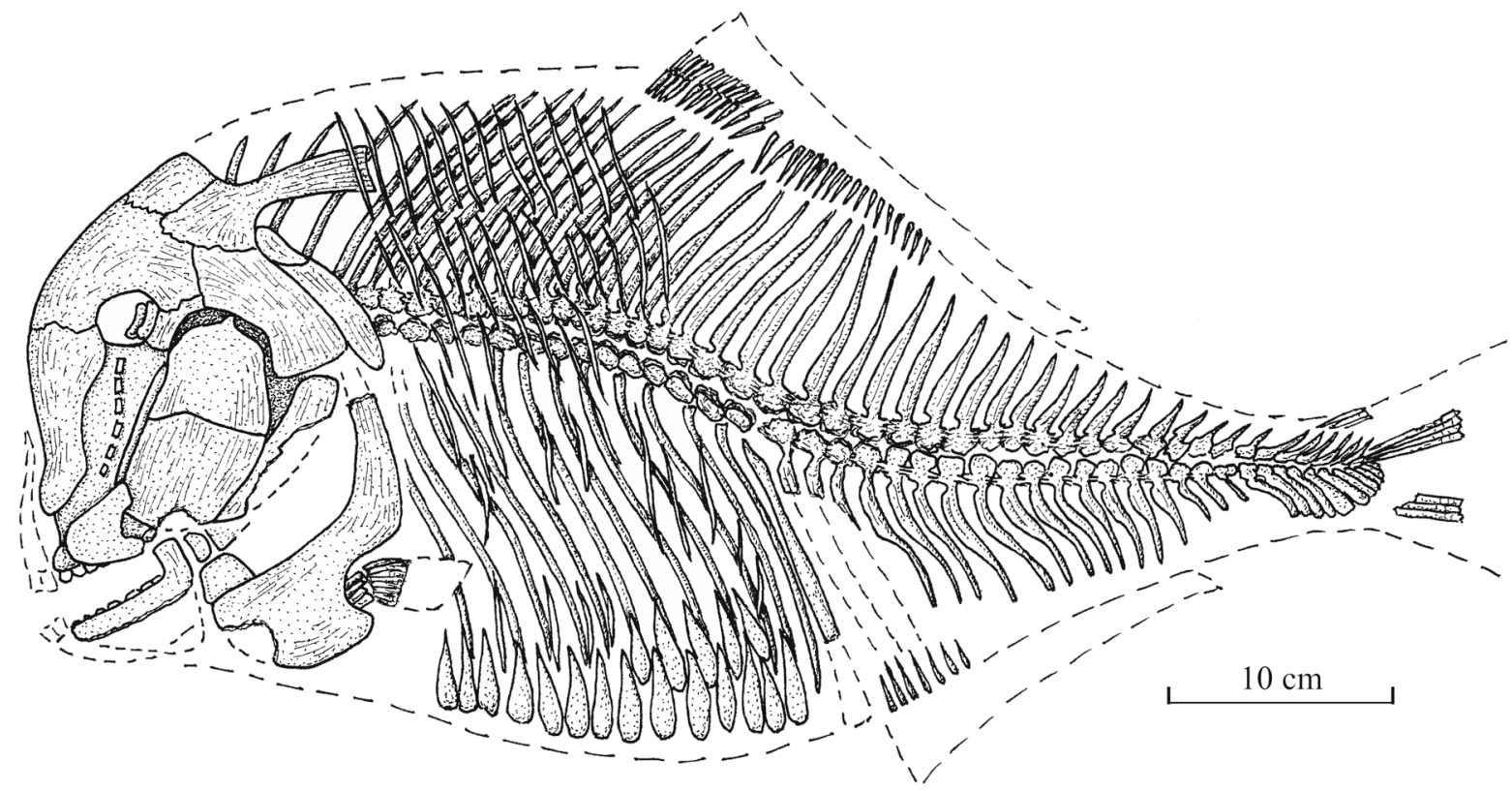

Fig. 14. Sigmapycnodus giganteus gen. et sp. nov., holotype, reconstruction (CLC S-497a, b). 
dermopterotic is hypertrophied, broad and high. There is no temporal fenestra. Only a small part of the parasphenoid is visible. The dermosphenotic is sutured to the dermopterotic and the frontal, becoming a lateral part of the dermal skull roof. The ventral margin of the dermosphenotic and of the dermopterotic is located at the level of the ventral border of the orbit. A deep and extremely enlarged dilatator fossa is present between the dermosphenotic and the dermopterotic. The autosphenotic and the sensory canals of the skull roof are not visible.

The quadrate, a part of the entopterygoid and a very small ectopterygoid are preserved on the slab $b$ (Fig. 13) of the holotype, but not the symplectic.

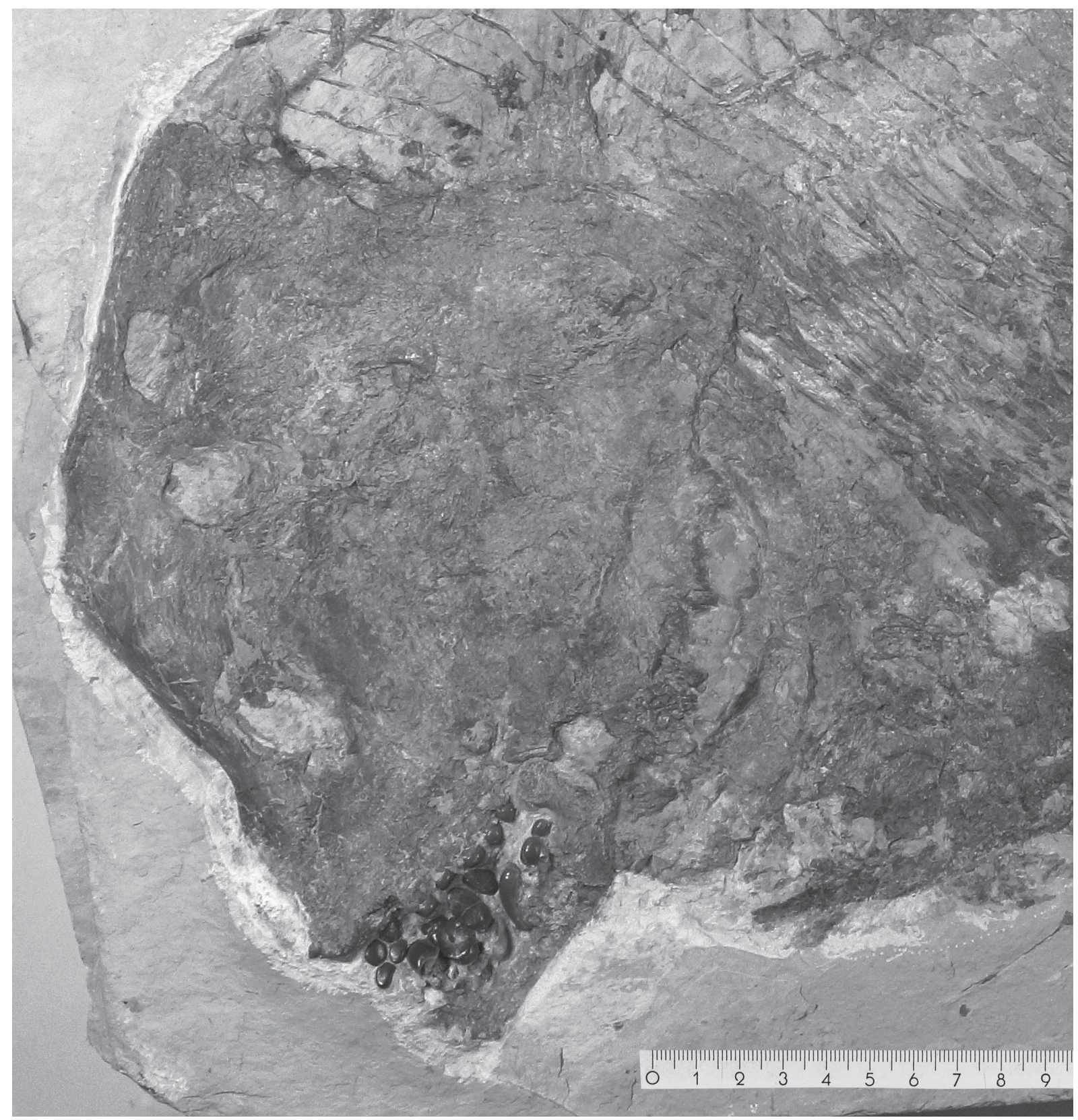

Fig. 15. Sigmapycnodus giganteus gen. et sp. nov., holotype, head region (CLC S-497a). 
TAVERNE L. \& CAPASSO L., Two new pycnodontiform fishes from the Cretaceous of Lebanon

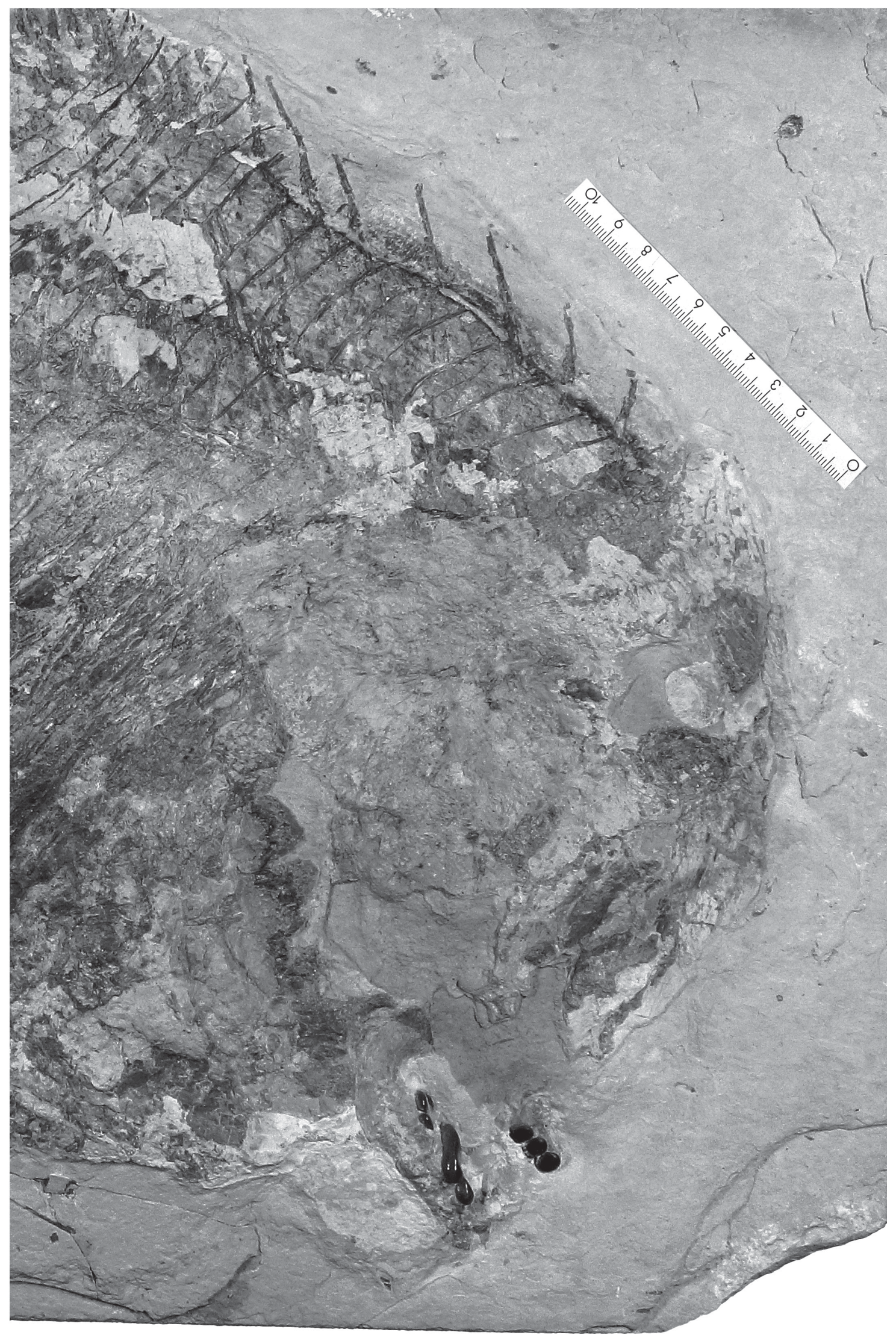

Fig. 16. Sigmapycnodus giganteus gen. et sp. nov., holotype, head region (CLC S-497b.) 


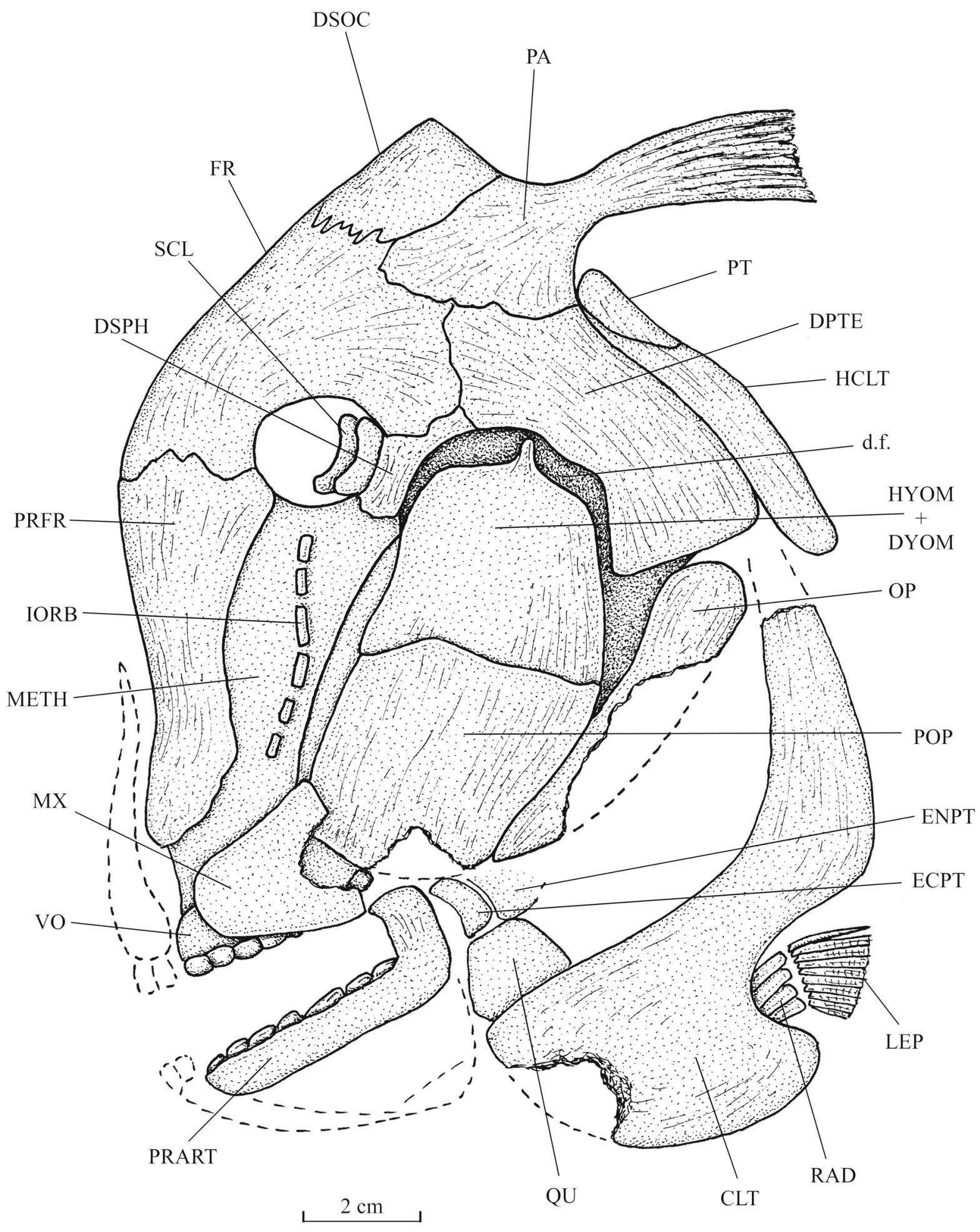

Fig. 17. Sigmapycnodus giganteus gen. et sp. nov., holotype, skull and pectoral girdle (CLC S-497a, b). 


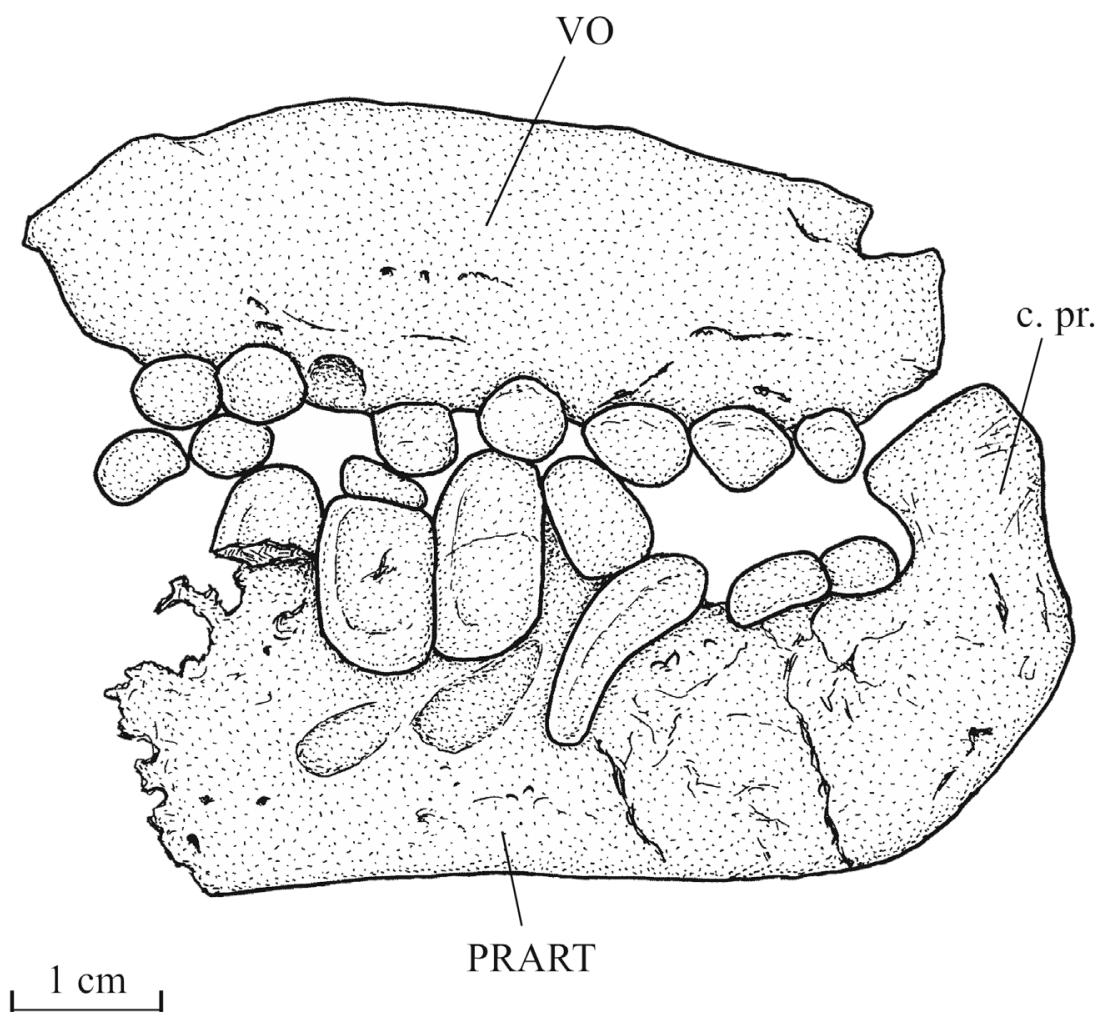

Fig. 18. Sigmapycnodus giganteus gen. et sp. nov., holotype, vomer and prearticular (CLC S-497a).
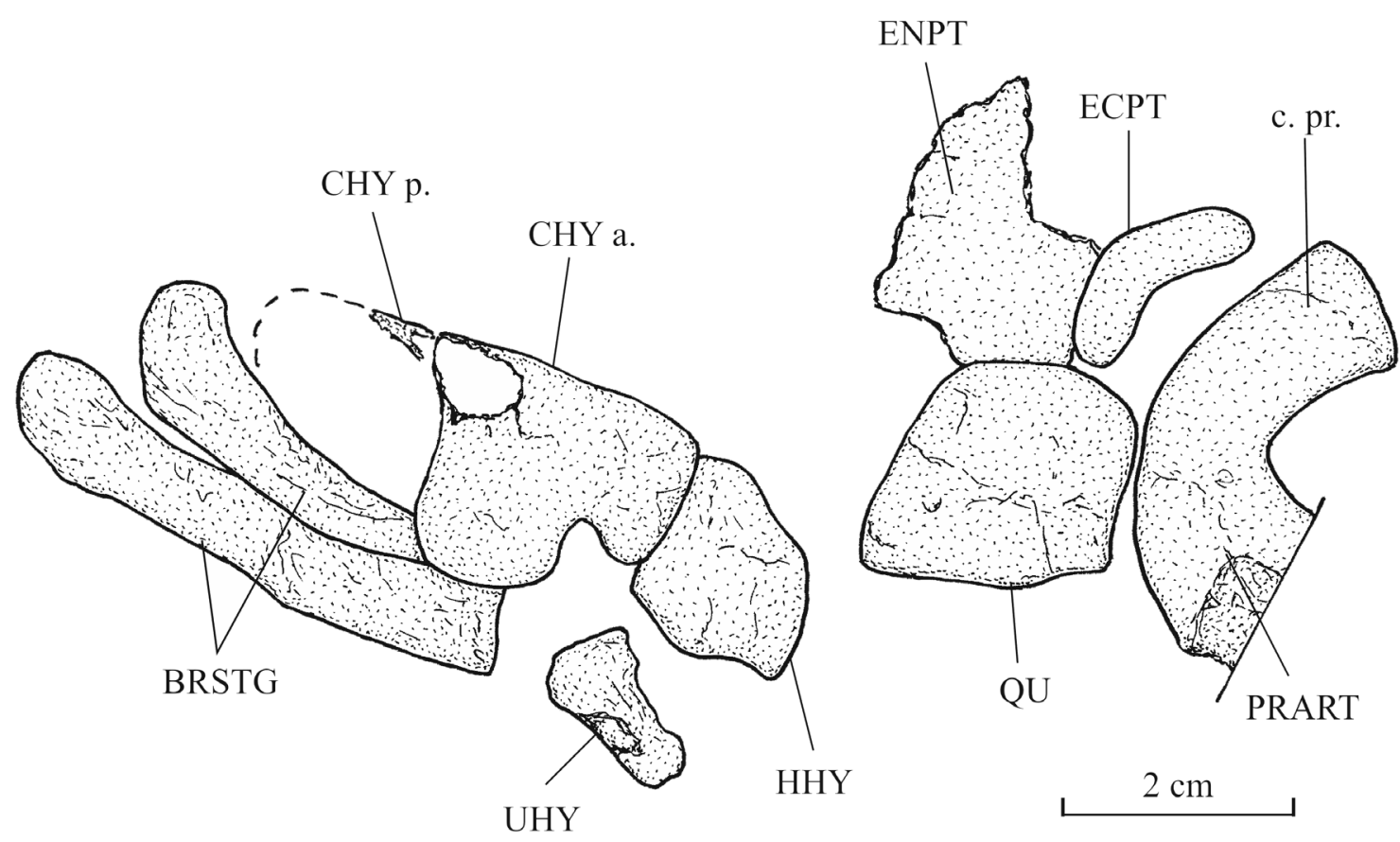

Fig. 19. Sigmapycnodus giganteus gen. et sp. nov., holotype, hyoid bar and coronoid region (CLC S-497b). 
The maxilla is a large plate-like bone, broader posteriorly than anteriorly. There is a deep and broad notch in its posterior margin. The prearticular is long but rather narrow, with a strongly developed coronoid process. It bears at least two rows of molariform teeth still larger than those on the vomer. The dorsal row contains six teeth and the ventral row three teeth, with the last one longer than the others. These teeth are ovoid in shape with a more or less flat surface. The premaxilla, the dentary, the angular and the articular are not preserved.

A series of six small tubular infraorbitals, vertically oriented, is present along the mesethmoid. They connect the infraorbital and the rostral sensory canals. Paired sclerotic bones are visible in the orbit, close to the dermosphenotic.

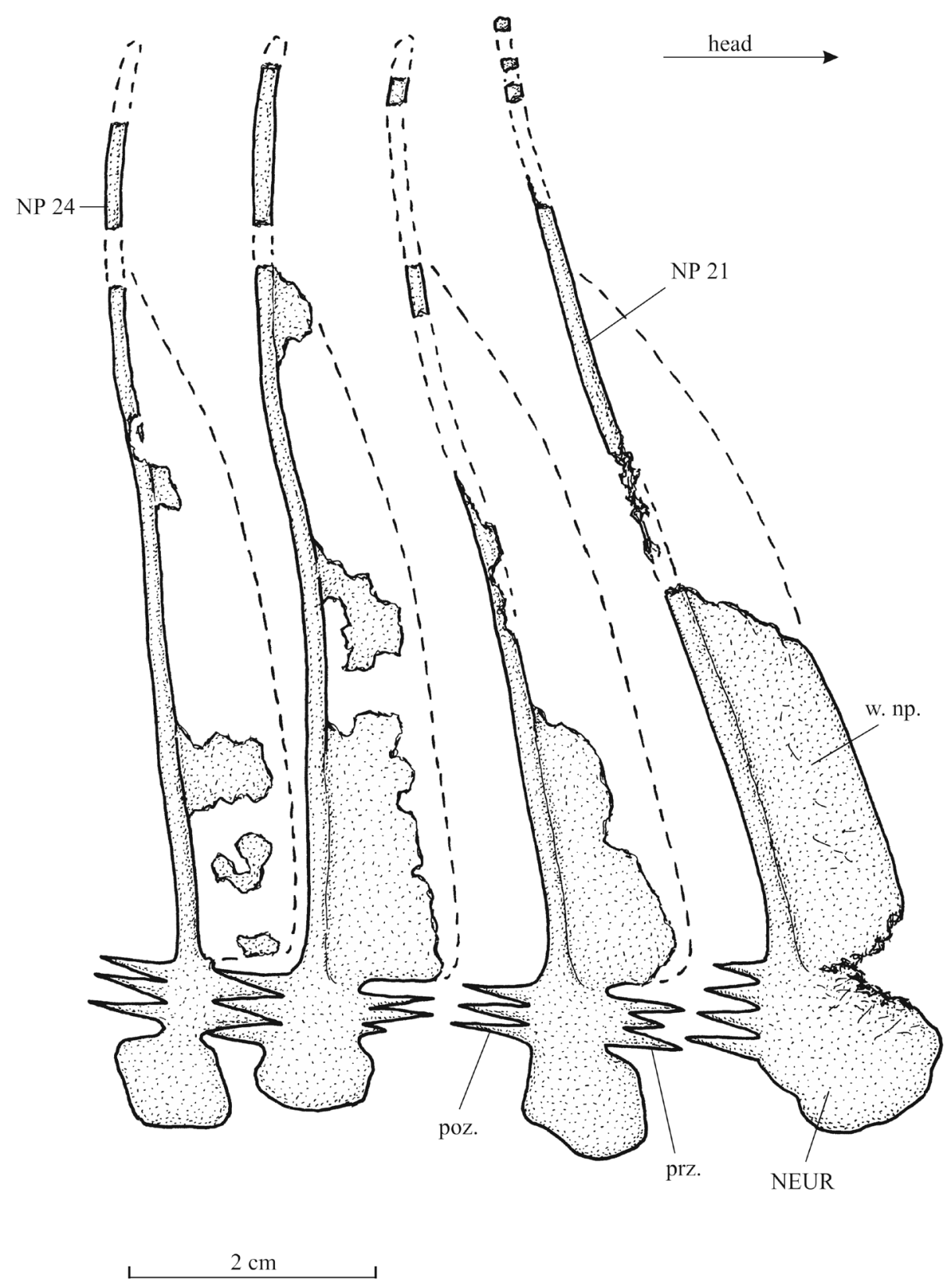

Fig. 20. Sigmapycnodus giganteus gen. et sp. nov., holotype, neural arches and spines 21-24 (CLC S-497b), showing the hypercomplex contact between the arcocentra. 
The hyomandibula-dermohyomandibula and the preopercle are sutured together. The exposed part of the hyomandibula-dermohyomandibula has the same depth as the preopercle. As seen on slab a (Fig. 12) of the holotype, the dorsal margin of the hyomandibula bears a small pointed process that penetrates the dilatator fossa.

A large hypohyal, a short anterior ceratohyal, a very small fragment of the posterior ceratohyal, two broad branchiostegal rays and a possible urohyal are preserved on slab b (Fig. 13) of the holotype.

\section{Girdles (Figs 15-17)}

The short posttemporal and the long hypercleithrum (= supracleithrum) are pressed against the posterior margin of the dermopterotic. The cleithrum has a short but very broad ventral branch and a much narrower dorsal branch. There is a sinus in the posterior margin of the bone between the two branches to house the short pectoral fin. At least four pterygiophores are present. The number of pectoral rays is not determinable.

The pelvic girdle is lost, due to the bad preservation.

Axial skeleton (Figs 12-14, 20)

The skeletal axis is badly preserved. In the rare places where the neural and haemal archocentra are more or less complete, these arches surround totally the notochord. In the caudal region of the body, the arcocentra are in hypercomplex contact, involving three or for pre- and postzygapophyses for each centrum. There are 41 neural spines before the epichordal series. Only 39 neural spines are visible on slab a (Fig. 12), but two more posterior spines are present on slab b (Fig. 13). It is not possible to see if the first neural spines were autogenous or not. There are at least 17 haemal spines anterior to the hypochordal elementss but one or two spines seemingly are missing. There are 11 or 12 pairs of ribs. The postcoelomic bone is thin but very long.

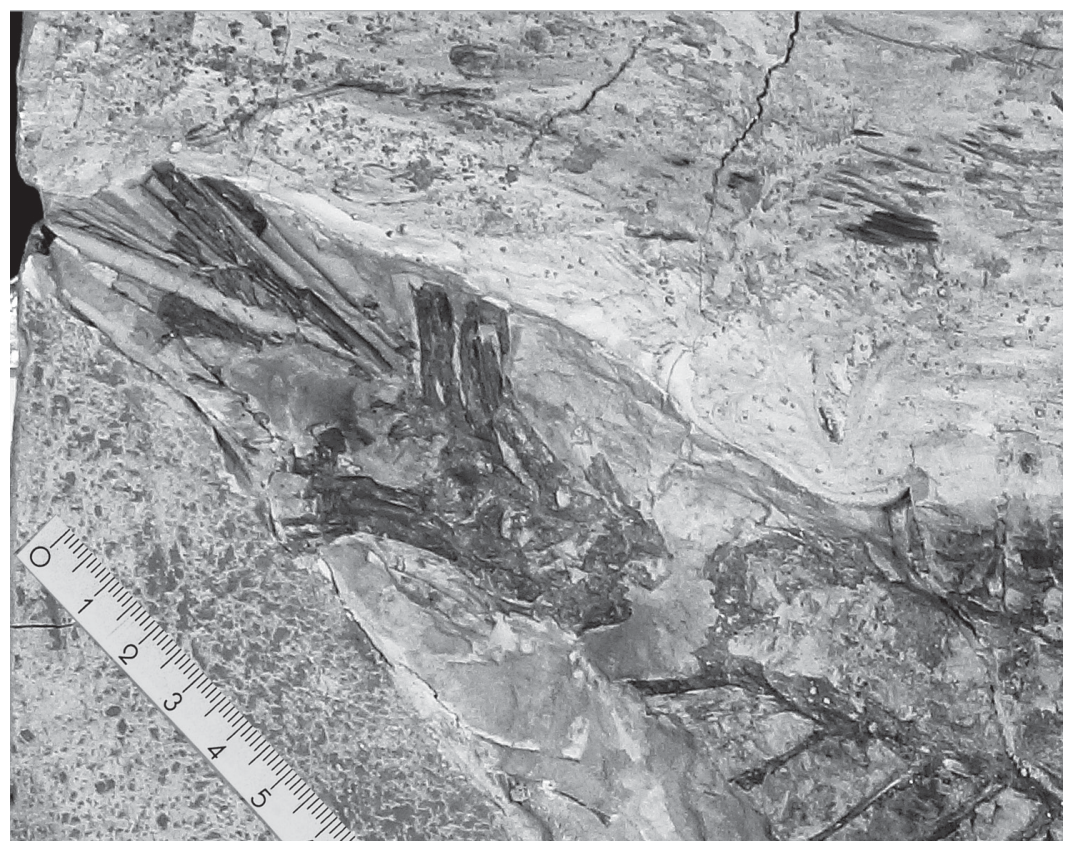

Fig. 21. Sigmapycnodus giganteus gen. et sp. nov., holotype, tail region (CLC S-497b). 


\section{Dorsal and anal fins}

The dorsal fin origin is far posterior to the head. The fin is incomplete. The first 29 dorsal pterygiophores are preserved on slab a (Fig. 12). The basis of the first 11 rays is visible on slab b (Fig. 13).

The anal fin inserts at a posterior level than the dorsal one. Small fragments of a few anterior anal pterygiophores are present on slab b (Fig. 13).

\section{Caudal skeleton (Figs 21-22)}

The caudal peduncle is well marked but its dorsal and ventral margins are not visible and its depth is not determinable. The caudal skeleton is much better preserved on slab b (Fig. 13) than on slab a (Fig. 12). There are six epichordals, 11 hypochordals and one urodermal. The epichordals are long and the first six hypochordals are comparably longer. The sixth and probably the seventh hypochordals are broadened but there is no real hypertrophy.

Only parts of a few caudal rays are preserved. The size and shape of the caudal fin are unknown.

\section{Squamation}

The scales cover only the abdominal region of the body. Most of them are reduced to scale bars but ventrally a few complete scales are present.

Dorsal ridge scutes and the scales of the cloacal region are not preserved.

Some spiny scutes of the ventral keel are visible but the total number of these elements is not determinable.

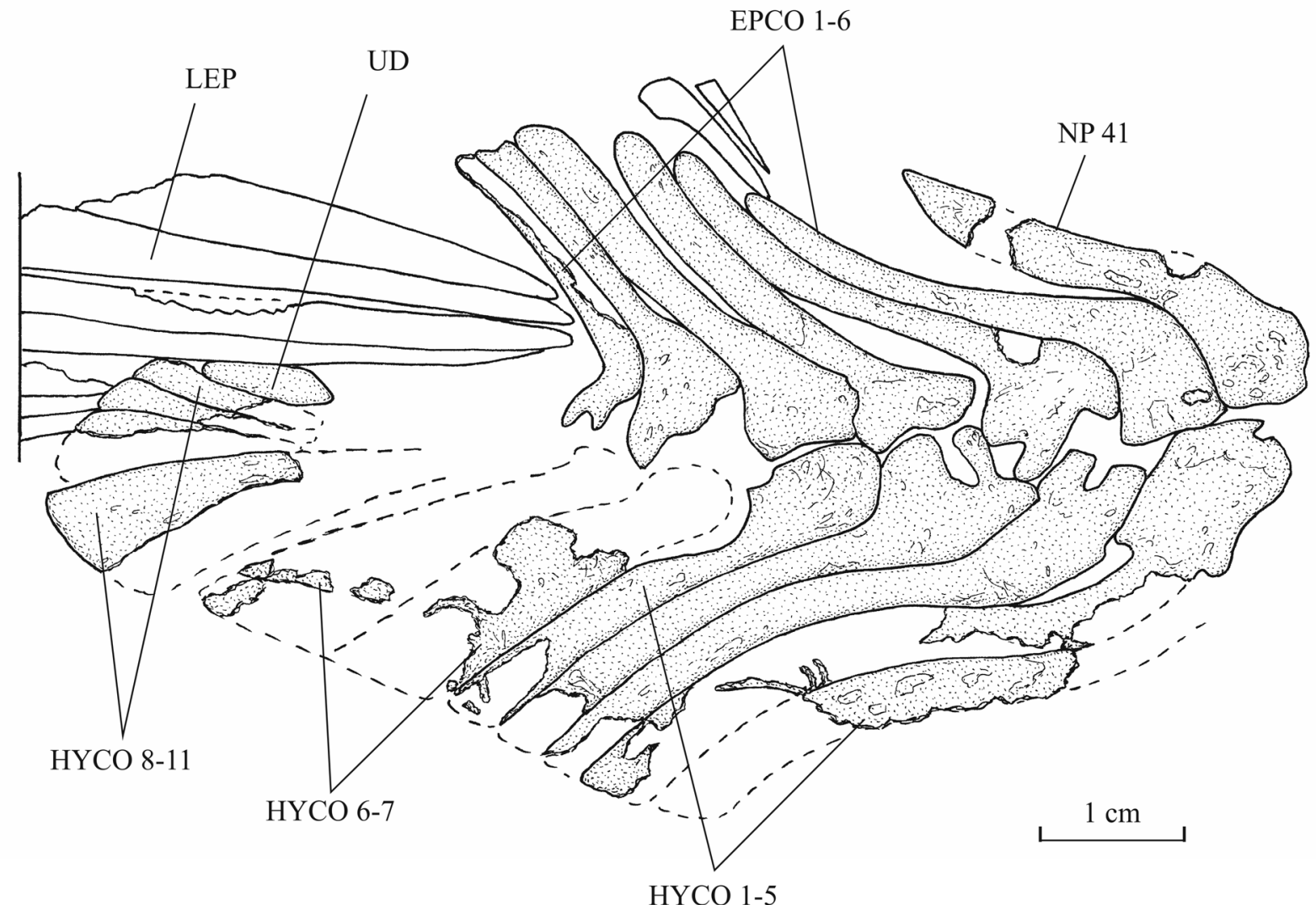

Fig. 22. Sigmapycnodus giganteus gen. et sp. nov., holotype, caudal skeleton (CLC S-497a, b). 


\section{Discussion}

The systematic position of Libanopycnodus gen. nov. and Sigmapycnodus gen. nov. within Pycnodontomorpha

Libanopycnodus gen. nov. and Sigmapycnodus gen. nov. have a large brush-like process on the parietal. This anatomical structure is the major apomorphy of the Pycnodontidae (Poyato-Ariza \& Wenz 2002: node 13, character 14[1]). The two new genera certainly belong to this family. No other member of the Pycnodontomorpha exhibits such a parietal peniculus.

\section{The systematic position of Libanopycnodus gen. nov. within Pycnodontidae}

Libanopycnodus gen. nov. has a bifid cloacal scale. The presence of a bifid scale is one of the main apomorphies of the Pycnodontinae and Nursalliinae, two subfamilies of the family Pycnodontidae (Poyato-Ariza \& Wenz 2002: node 23, character 104[1]). This bifid cloacal scale is present even in the most basal Pycnodontinae described until now, Pseudopycnodus nardoensis (Taverne 1997). This Italian fossil fish was originally described as lacking a bifid cloacal scale, because the description was unfortunately based on a specimen having lost the bifid scale due to the fossilisation (Taverne 2003: fig. 11). In specimen CLC S-467 of Pseudopycnodus nardoensis, the bifid cloacal scale is clearly present (Fig. 23).

However, the new Lebanese genus could not be referred to the Nursalliinae. The members of that subfamily differ from it by their neural and haemal arches in hypercomplex contact, by their two or three greatly hypertrophied hypochordals, by their vertical caudal fin and by the presence of scales in an important part of the posterior region of the body. A systematic position within Pycnodontinae seems thus the most probable.

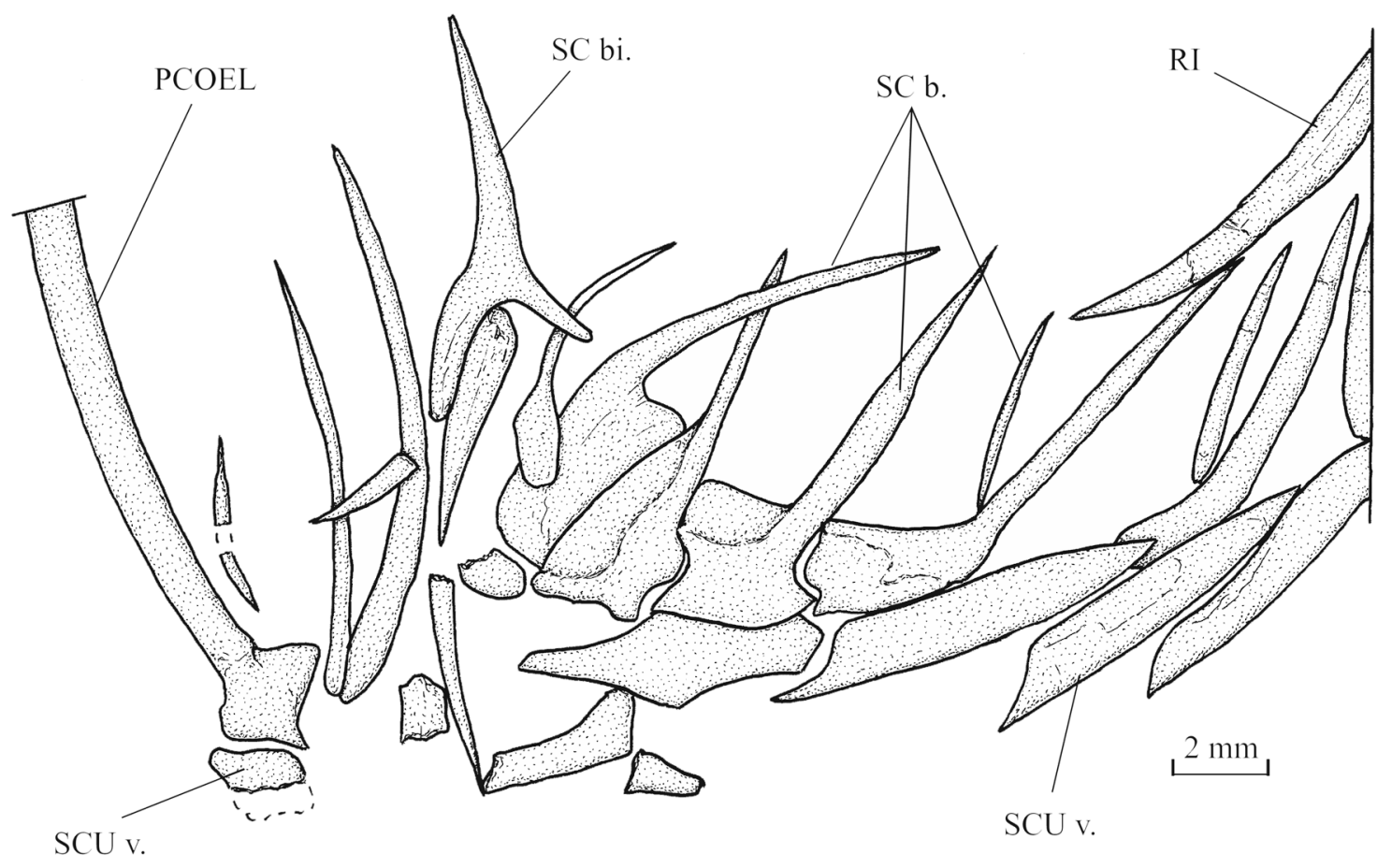

Fig. 23. Pseudopycnodus nardoensis (Taverne, 1997), cloacal region of specimen CLC S-467. 
At least two other features confirm the subfamilial position of Libanopycnodus gen. nov., as shown hereafter.

In this fossil fish, there is a postorbital shortening of the skull roof and the most posterior part of the endocranium is exposed (Poyato-Ariza \& Wenz 2002: character 19[1]). This peculiar character is only known in the Pycnodontinae and is present in all the members of the subfamily (Taverne 1997: figs 2, 4; Capasso 2000: figs 3, 7A, 8; Poyato-Ariza \& Wenz 2002: fig. 11B; Poyato-Ariza 2010: fig. 3, 2013 : 94).

In Libanopycnodus gen. nov., the dermosphenotic is not a free bone. It is incorporated in the lateral wall of the skull roof and is sutured to the frontal and the dermopterotic. The lower margin of the dermosphenotic and of the dermopterotic occupies a low position, at the level of the ventral border of the orbit. The dermosphenotic and the dermopterotic surround a large, deep and well-visible dilatator fossa in which the hyomandibula is articulated. These characters also are typical of the Pycnodontinae (Taverne \& Capasso 2012: fig. 13, characters 1,3), a subfamily in which the new genus could confidently be allocated.

\section{The systematic position of Libanopycnodus gen. nov. within Pycnodontinae}

Besides Libanopycnodus gen. nov., the subfamily Pycnodontinae contains six other genera, Pycnodus Agassiz, 1833 from the Eocene of Italy and other countries, Tergestina Capasso, 2000 from the Paleocene of north Italy, Pseudopycnodus Taverne, 2003 from the Campanian-Maastrichtian of southern Italy, Oropycnodus Poyato-Ariza \& Wenz, 2002 from the Paleocene of France, Polazzodus Poyato-Ariza, 2010 from the Santonian of northern Italy and Sylvienodus Poyato-Ariza, 2013 from the Cenomanian of Portugal. Data on these six other genera hereafter mentioned come from Blot (1987), Taverne (1997, 2003), Capasso (2000), Poyato-Ariza \& Wenz (2002), Poyato-Ariza $(2010,2013)$ and Taverne \& Capasso (2012).

Oropycnodus and Pycnodus possess a dermocranial fenestra and the adjacent arcocentra are in hypercomplex contact, two advanced characters not present in Libanopycnodus gen. nov. and the other genera of the subfamily.

In Tergestina, Sylvienodus, Oropycnodus and Pycnodus, the dorsal ridge scutes are scutellum-like, with a spiny upper margin. This apomorphy is not yet present in Libanopycnodus gen. nov., Pseudopycnodus and Polazzodus.

Almost all Pycnodontiformes, including Pseudopycnodus and Libanopycnodus gen. nov., have a preopercle much deeper than the exposed part of the hyomandibula-dermohyomandibula. The other Pycnodontinae, Polazzodus, Tergestina, Oropycnodus, Sylvienodus and Pycnodus, share an unusual apomorphy. The exposed portion of their hyomandibula-dermohyomandibula is as deep or even deeper than the preopercle.

Hence, it appears that Libanopycnodus gen. nov. and Pseudopycnodus are the two most basal genera of the subfamily. However, these two fishes cannot be confounded. They differ by numerous characters, for instance the shape and size of the parietal, the dermopterotic, the preopercle, the opercle, the coronoid process, the cleithrum and the dorsal ridge scutes. They have a quite different number of dorsal and anal pterygiophores and of principal caudal rays. In Pseudopycnodus, the orbitosphenoid, pleurophenoid, basisphenoid and prootic are clearly apparent in the posterior part of the orbit. That is not the case in Libanopycnodus gen. nov.

The exposed region of the hyomandibula-dermohyomandibula is proportionally wider in Pseudopycnodus than in Libanopycnodus gen. nov., a situation that announces the peculiar development 
of this bone in the more derived genera of the subfamily. Libanopycnodus gen. nov. seems thus a little less advanced than Pseudopycnodus and is therefore the most basal member of the Pycnodontinae described until now.

\section{The systematic position of Sigmapycnodus gen. nov. within Pycnodontidae}

The cloacal region of Sigmapycnodus gen. nov. is missing, due to the state of fossilization, and we do not know whether a cloacal bifid scale, the main synapomorphy of the Pycnodontinae, was present or not. However, the new fossil genus has the dermosphenotic sutured to the lateral wall of the skull roof and exhibits an enormous and well-visible dilatator fossa surrounded by the dermopterotic and the dermosphenotic, two bones of which the ventral margin reaches the level of the lower margin of the orbit. As previously stated, these features are characteristic of the Pycnodontinae.

Two other characters confirm the subfamilial position of Sigmapycnodus gen. nov., as explained hereafter.

In the new Lebanese genus, the exposed part of the hyomandibula-dermohyomandibula has the same depth as the preopercle. This peculiar feature only occurs in some Pycnodontinae.

In Sigmapycnodus gen. nov., the arcocentra are in hypercomplex contact. This specialized character only exists in the subfamily Nursalliinae and in a few Pycnodontinae. But the new Lebanese genus does not possess the apomorphies that characterize the Nursalliinae.

Thus, we can confidently conclude that Sigmapycnodus gen. nov. belongs to the subfamily Pycnodontinae.

It is to be noted that the posterior region of the endocranium is not visible in Sigmapycnodus gen. nov., an unusual condition for a pycnodontinid fish. The hypertrophy of the dermopterotic in the new Lebanese genus probably explains that peculiar condition.

\section{The systematic position of Sigmapycnodus gen. nov. within Pycnodontinae}

Sigmapycnodus gen. nov. has the exposed region of the hyomandibula-dermohyomandibula as deep as the preopercle, an apomorphy shared by Polazzodus, Tergestina, Sylvienodus, Oropycnodus and Pycnodus but not yet present in Libanopycnodus gen. nov. and Pseudopycnodus.

Sigmapycnodus gen. nov., Oropycnodus and Pycnodus possess arcocentra in hypercomplex contact, an apomorphy absent in the other genera of the subfamily.

Oropycnodus and Pycnodus exhibit a dermocranial fenestra, a specialized feature that is missing in Sigmapycnodus gen. nov. and in the other Pycnodontinae.

On the basis of these characters, it appears that within Pycnodontinae Sigmapycnodus gen. nov. occupies an intermediate position between Libanopycnodus gen. nov., Pseudopycnodus, Polazzodus, Tergestina and Sylvienodus, on the one hand, and Oropycnodus and Pycnodus, on the other hand.

\section{Acknowledgements}

We greatly thank Dr Silvano Agostini, Superintendant of the Soprintendenza per i Beni Archeologici dell'Abruzzo - Chieti, for allowing us to study the fossil fishes of Luigi Capasso's collection. We are grateful to Mr A. Vandersypen (Royal Belgian Institute of Natural Sciences) and to Mr L. Lullo (University of Chieti) for their technical help. We are also indebted to the anonymous reviewers who have read and commented on our text. 


\section{References}

Blot J. 1987. L'ordre des Pycnodontiformes. Studi e Ricerche sui Giacimenti Terziari di Bolca V. Museo Civico di Storia Naturale, Verona.

Capasso L. 2000. Tergestina sorbinii gen. nov., sp. nov., del Paleocene inferiore di Trebiciano, Trieste (Pisces, Pycnodontiformes). Atti del Museo Civico di Storia Naturale di Trieste 48: 261-289.

Kriwet J. 2001. Palaeobiogeography of pycnodontiform fishes (Actinopterygii, Neopterygii). In: Melendez G., Herrerz Z., Delvene G. \& Azanza B. (eds) Los fósiles y la paleogeographia. XII Jornadas de la Sociedad Española de Paleontologia: 121-130. Universidad de Zaragoza, Zaragoza.

Marramà G., Villier B., Dalla Vecchia F.M. \& Carnevale G. 2016. A new species of Gladiopycnodus (Coccodontoidea, Pycnodontomorpha) from the Cretaceous of Lebanon provides new insights about the morphological diversification of pycnodont fishes through time. Cretaceous Research 61: 34-43. https://doi.org/10.1016/j.cretres.2015.12.022

Martin-Abad H. \& Poyato-Ariza F.J. 2013. Historical patterns of distribution in Pycnodontiform and Amiiform fishes in the context of moving plates. Geologica Belgica 16 (4): 217-226. Available from https://popups.uliege.be:443/1374-8505/index.php?id=4243 [accessed 5 Mar. 2018].

Nursall J.R. 1996. Distribution and ecology of pycnodont fishes. In: Arratia G. \& Viohl G. (eds) Mesozoic Fishes - Systematics and Paleoecology: 115-124. Verlag Dr. F. Pfeil, Munich.

Poyato-Ariza F.J. 2010. Polazzodus, gen. nov., a new pycnodont fish from the Late Cretaceous of northeastern Italy. Journal of Vertebrate Paleontology 30 (3): 650-664.

https://doi.org/10.1080/02724631003762955

Poyato-Ariza F.J. 2013. Sylvienodus, a new replacement genus for the Cretaceous pycnodontiform fish "Pycnodus" laveirensis. Comptes Rendus Palevol 12:91-100. https://doi.org/10.1016/j.crpv.2013.01.001

Poyato-Ariza F.J. \& Wenz S. 2002. A new insight into pycnodontiform fishes. Geodiversitas 24 (1): $139-248$.

Taverne L. 1997. Les poissons crétacés de Nardò. $5^{\circ}$. Pycnodus nardoensis sp. nov. et considérations sur l'ostéologie du genre Pycnodus (Actinopterygii, Halecostomi, Pycnodontiformes). Bollettino del Museo Civico di Storia Naturale di Verona 21: 437-454.

Taverne L. 2003. Les poissons crétacés de Nardò. 15. Étude complémentaire de Pseudopycnodus nardoensis (Taverne, 1997) nov. gen. (Actinopterygii, Halecostomi, Pycnodontiformes). Bollettino del Museo Civico di Storia Naturale di Verona, Geologia Paleontologia Preistoria 27: 15-28.

Taverne L. \& Capasso L. 2012. Les poissons crétacés de Nardò. $35^{\circ}$. Compléments à l'étude des halécostomes Belonostomus (Aspidorhynchiformes) et Pseudopycnodus (Pycnodontiformes). Bollettino del Museo Civico di Storia Naturale di Verona, Geologia Paleontologia Preistoria 36: 25-44.

Taverne L. \& Capasso L. 2013. Gladiopycnodontidae, a new family of pycnodontiform fishes from the Late Cretaceous of Lebanon, with the description of three genera. European Journal of Taxonomy 57: 1-30. https://doi.org/10.5852/ejt.2013.57

Taverne L. \& Capasso L. 2014a. Ostéologie et phylogénie des Coccodontidae, une famille remarquable de poissons Pycnodontiformes du Crétacé supérieur marin du Liban, avec la description de deux nouveaux genres. Palaeontos 25: 3-43.

Taverne L. \& Capasso L. 2014b. Ostéologie et relations phylogénétiques des Gebrayelichtyidae (Halecostomi, Pycnodontomorpha), une extraordinaire famille de poissons du Crétacé supérieur marin du Liban, avec la description d'un nouveau genre. Palaeontos 25: 44-68. 
Taverne L. \& Capasso L. 2014c. On the "Coccodus" lindstroemi species complex (Pycnodontiformes, Gladiopycnodontidae) from the marine Late Cretaceous of Lebanon, with the description of two new genera. European Journal of Taxonomy 101: 1-27. https://doi.org/10.5852/ejt.2014.101

Taverne L. \& Capasso L. 2016. New data on the osteology and phylogeny of Gladiopycnodontidae (Pycnodontiformes), a tropical fossil fish family from the marine Upper Cretaceous of Lebanon, with the description of four genera. Geo-Eco-Trop 39 (2): 217-246. Available from http://www.geoecotrop.be/index.php?page=numero-39 [accessed 5 Mar. 2018].

Taverne L., Maisey J.G. \& Capasso L. 2015. A third longirostrine gladiopycnodontid fish genus (Pycnodontiformes) from the marine Late Cretaceous of Lebanon. Palaeontos 28: 37-42.

Manuscript received: 14 February 2017

Manuscript accepted: 22 September 2017

Published on: 28 March 2018

Topic editor: Christian de Muizon

Desk editor: Kristiaan Hoedemakers

Printed versions of all papers are also deposited in the libraries of the institutes that are members of the EJT consortium: Muséum national d'Histoire naturelle, Paris, France; Botanic Garden Meise, Belgium; Royal Museum for Central Africa, Tervuren, Belgium; Natural History Museum, London, United Kingdom; Royal Belgian Institute of Natural Sciences, Brussels, Belgium; Natural History Museum of Denmark, Copenhagen, Denmark; Naturalis Biodiversity Center, Leiden, the Netherlands; Museo Nacional de Ciencias Naturales-CSIC, Madrid, Spain; Real Jardín Botánico de Madrid CSIC, Spain. 